Article

\title{
Thermal, Mechanical and UV-Shielding Properties of Poly(Methyl Methacrylate)/Cerium Dioxide Hybrid Systems Obtained by Melt Compounding
}

\author{
María A. Reyes-Acosta ${ }^{1}$, Aidé M. Torres-Huerta ${ }^{1, *}$, Miguel A. Domínguez-Crespo ${ }^{1}$, \\ Abelardo I. Flores-Vela ${ }^{2}$, Héctor J. Dorantes-Rosales ${ }^{3}$ and José A. Andraca-Adame ${ }^{4}$ \\ ${ }^{1}$ Instituto Politécnico Nacional, CICATA-Altamira, Km 14.5 Carretera Tampico-Puerto Industrial \\ Altamira, C.P. 89600 Altamira, Tamps. Mexico; \\ E-Mails: mreyesa0803@alumno.ipn.mx (M.A.R.-A.); mdominguezc@ipn.mx (M.A.D.-C.) \\ ${ }^{2}$ Instituto Politécnico Nacional, CMP+L, Av. Acueducto s/n, Barrio La Laguna, \\ Col. Ticomán, C.P. 07340, México D.F., Mexico; E-Mail: afloresv@ipn.mx \\ ${ }^{3}$ Instituto Politécnico Nacional, ESIQIE, Departamento de Metalurgia, C.P. 07738 México D.F., Mexico; \\ E-Mail: hdorantes@ipn.mx \\ ${ }^{4}$ Instituto Politécnico Nacional, CNMN, Av. Luis Enrique Erro S/N, Unidad Profesional Adolfo López \\ Mateos, Zacatenco, C.P. 07738, México D.F., Mexico; E-Mail: jandraca@ipn.mx \\ * Author to whom correspondence should be addressed; E-Mail: atorresh@ipn.mx; \\ Tel.: +833-260-0125 (ext. 87505); Fax: +833-2649301.
}

Academic Editor: Lloyd M. Robeson

Received: 30 June 2015 / Accepted: 29 August 2015 / Published: 7 September 2015

\begin{abstract}
Thick and homogeneous hybrid film systems based on poly(methyl methacrylate) (PMMA) and $\mathrm{CeO}_{2}$ nanoparticles were synthesized using the melt compounding method to improve thermal stability, mechanical and UV-shielding properties, as well as to propose them for use in the multifunctional materials industry. The effect of the inorganic phase on these properties was assessed by using two different weight percentages of synthesized $\mathrm{CeO}_{2}$ nanoparticles $(0.5$ and $1.0 \mathrm{wt} \%)$ with the sol-gel method and thermal treatment at different temperatures $\left(120,235,400,600\right.$ and $\left.800{ }^{\circ} \mathrm{C}\right)$. Thereafter, the nanoceria powders were added to the polymer matrix by single screw extrusion. The absorption in the UV region was increased with the crystallite size of the $\mathrm{CeO}_{2}$ nanoparticles and the $\mathrm{PMMA} / \mathrm{CeO}_{2}$ weight ratio. Due to the crystallinity of $\mathrm{CeO}_{2}$ nanoparticles, the thermal, mechanical and UV-shielding properties of the PMMA matrix were improved. The presence of $\mathrm{CeO}_{2}$
\end{abstract}


nanostructures exerts an influence on the mobility of PMMA chain segments, leading to a different glass transition temperature.

Keywords: PMMA; $\mathrm{CeO}_{2}$ nanoparticles; thermal properties; UV-shielding properties

\section{Introduction}

In the last years, there has been an increased tendency to use thermoplastic polymers such as polycarbonate (PC), polymethylmethacrylate (PMMA) and polyethylene-tetrafluoroethylene (PTFE) in diverse industrial applications due to their low weight and high transparency [1,2]. PMMA is one of the most commonly used thermoplastic polymers in the construction industry because of its excellent optical properties (it transmits light in the 360-1000 nm range almost without loss [3]), impact and shatter properties (compared to inorganic glass), and relatively high weathering resistances. In addition, PMMA polymer has very low thermal conductivity $(\sim 0.0012 \mathrm{cal} / \mathrm{s} \mathrm{cm} \mathrm{K})$, which makes it a candidate to be used as a thermal-control interface material [4,5]. Unfortunately, PMMA and other polymers decompose or degrade under solar UV radiation (200-400 nm) [6]. The most damaging natural UV radiation is between 290 and $350 \mathrm{~nm}$ where the highest energy of the solar spectrum occurs [7]. The usage of inorganic UV absorbers can be a good alternative for the stability of thermoplastic polymers under weather conditions. Wide band-gap oxides such as titanium dioxide $\left(\mathrm{TiO}_{2}\right)$ and zinc oxide $(\mathrm{ZnO})$ have been added as inorganic fillers into the PMMA matrix in order to modify its optical properties in the UV region [8-12]. As one of the most versatile semiconductors, cerium dioxide $\left(\mathrm{CeO}_{2}\right)$ can be used as a solar absorber. $\mathrm{CeO}_{2}$ has shown good thermal and chemical stabilities, a high refractive index in the visible region (2.1-2.2), good transmittance in the visible spectrum and low cost due to the fact that it is one of the most abundant rare earth elements [13-15]. It has also potential applications such as in fuel and solar cells, catalysts, oxygen sensors, polishing agents, gate oxides, optical devices and coating materials [16-18]. Moreover, due to its broad band gap (BG) of 2.7-3.4 eV, depending on the preparation method, effective absorption in the ultraviolet range can be ensured by this material $(\lambda<400 \mathrm{~nm})[7,19]$. The incorporation of UV-shielding-nano $\mathrm{CeO}_{2}$ into the PMMA polymer matrix can produce functional nanocomposites, which can be a better way of making effective solar-thermal-control-interface structures for delaying polymer degradation. Different techniques have been used for the preparation of $\mathrm{CeO}_{2}$, including coprecipitation, microemulsion, microwave-assisted thermal decomposition, combustion synthesis, and mechanochemical, sol-gel, hydrothermal, solvothermal and electrochemical methods [20-22]. Among them, the sol-gel method has been widely used because it allows the synthesis of ultrafine powders with well-controlled properties such as homogeneity, purity, microstructure, particle size, and morphology, at relatively low cost [7,23-26].

Based on the above, it is clear that the development of an interface displaying superior UV-NIR shielding for degradation control without losing its mechanical properties is in high demand. Recently, the use of PMMA/CeO $\mathrm{C}_{2}$ nanocomposites in the synthesis of a core/shell structure via the electrostatic interaction and polysiloxane $@ \mathrm{CeO}_{2}$ microspheres with multifunctional properties has been reported [13,27], but until now the effects of the crystallinity and amount of $\mathrm{CeO}_{2}$ nanoparticles on the thermal stability, mechanical and UV-NIR-shielding properties of these structures have not been reported. In this 
paper, the preparation and characterization of UV-protective coatings composed of sol-gel-derived $\mathrm{CeO}_{2}$ nanoparticles and dispersed in a PMMA polymer matrix by single screw extrusion are reported. The effect of different thermal treatments $\left(120,235,400,600\right.$ and $\left.800^{\circ} \mathrm{C}\right)$, crystallite sizes and nanoceria contents ( 0.5 and $1.0 \mathrm{wt} \%)$ on the optical, thermal and mechanical properties of PMMA are studied in detail.

\section{Experimental Section}

\subsection{Materials and Synthesis of $\mathrm{CeO}_{2}$ Nanoparticles}

$\mathrm{CeO}_{2}$ nanoparticles were synthesized using the sol-gel method starting from cerium nitrate hexahydrate $\left(\mathrm{Ce}\left(\mathrm{NO}_{3}\right)_{3} \cdot 6 \mathrm{H}_{2} \mathrm{O}\right.$, Aldrich, $\geqslant 98 \%$, St. Louis, MS, USA) as precursor and ethanol $\left(\mathrm{CH}_{3} \mathrm{CH}_{2} \mathrm{OH}\right.$, Aldrich $99.5 \%$, St. Louis, MS, USA) as solvent, using the following procedure: cerium nitrate was mixed with ethanol $(0.3 \mathrm{M})$ at room temperature while it was vigorously stirred by means of a magnetic stirrer for $2 \mathrm{~h}$ to yield a stable and transparent sol without precipitation or turbidity. The $\mathrm{pH}$ was fairly constant during the synthesis process $(\mathrm{pH} \approx 6)$. The $\mathrm{CeO}_{2}$ powders were obtained by gelification of the solutions and the gels drying at $120{ }^{\circ} \mathrm{C}$ for $24 \mathrm{~h}$ to remove organic matter; afterwards, the xerogel samples were ground in an agate mortar and then thermally treated in air at 235, 400, 600 and $800{ }^{\circ} \mathrm{C}$ for $2 \mathrm{~h}$ to study the structure and particle size effects. Finally, the powders were crushed by a horizontal ball mill at $350 \mathrm{rpm}$ for $10 \mathrm{~h}$. As is well known, the particle size distribution depends on various factors such as synthesis method, process parameters and in this case thermal treatment. Thus, the milling process was only used to uniform the particle size in each experiment before to obtain nanocomposites.

\subsection{Preparation of Hybrid Systems}

Commercial grade PMMA pellets (Plexiglas V825, Altuglas International, Arkema, Philadelphia, PA, USA) were used as raw material in this study. As first step, PMMA pellets were ground in a Thomas Wiley laboratory mill (Arthur H. Thomas Co., Philadelphia, PA, USA) using a $2 \mathrm{~mm}$ sieve to obtain fine particles. Thereafter, the polymeric particles were dried at $80^{\circ} \mathrm{C}$ for $1 \mathrm{~h}$ before being processed. $\mathrm{PMMA} / \mathrm{CeO}_{2}$ hybrid systems were prepared by using a laboratory single-screw extruder $(\mathrm{D}=19 \mathrm{~mm}$, $\mathrm{L} / \mathrm{D}=30 \mathrm{~mm})$ with three heating zones. Two different amounts of $\mathrm{CeO}_{2}$ nanostructures $(0.5$ and $1.0 \mathrm{wt} \%)$ were added to the polymer matrix. The extruder blending temperature profiles were 235 and $240{ }^{\circ} \mathrm{C}$ from hopper to die zone, and the screw rotating speed was $80 \mathrm{rpm}$; finally, nanocomposite films extrudates were cooled in a water bath at room temperature. For comparison during the characterizations and performance of nanocomposites, pure PMMA were ground and extruded under the same process conditions.

\subsection{Characterization and Measurements}

The IR spectra of the $\mathrm{CeO}_{2}$ nanoparticles and $\mathrm{PMMA} / \mathrm{CeO}_{2}$ hybrid systems were obtained within wavenumbers ranging from 4000 to $450 \mathrm{~cm}^{-1}$ using a Spectrum One Perkin-Elmer spectrometer (Perkin-Elmer Life and Analytical Sciences, Bridgeport, CT, USA). Transmission IR experiments were carried out under environmental conditions with 10 scans at a resolution of $4 \mathrm{~cm}^{-1}$. To determinate the interaction between the organic and inorganic phases, ${ }^{1} \mathrm{H} N M R$ and ${ }^{13} \mathrm{C}$ NMR spectra were carried out using a Bruker Ascend $750(750 \mathrm{MHz})$ NMR spectrometer for liquids (Bruker Instruments, Inc., Billerica, MA, USA) at room temperature with deuterated chloroform $\left(\mathrm{CDCl}_{3},{ }^{1} \mathrm{H}: \delta=7.26 \mathrm{ppm}\right.$, 
${ }^{13} \mathrm{C}: \delta=77.0 \mathrm{ppm}$, Sigma-Aldrich, 99.96\%, St. Louis, MS, USA) as solvent and tetramethylsilane (TMS, $\delta=0.00$ ppm, Sigma-Aldrich, NMR grade, $\geqslant 99.9 \%$, St. Louis, MS, USA) as the internal reference. Crystalline phase identification of the $\mathrm{CeO}_{2}$ powders and nanocomposites was performed using a D8 Advance Bruker X-ray diffractometer (Bruker AXS GmbH, Berlin, Germany) with $\mathrm{Cu}-\mathrm{K} \alpha$ monochromatic radiation (Bruker AXS GmbH, Berlin, Germany). The XRD patterns were collected in the $2 \theta$ range from 10 to $90^{\circ}$ at room temperature. $\mathrm{CeO}_{2}$ nanoparticles were examined by TEM using a JEOL-2000 FX-II microscope (JEOL Ltd., Akishima, Japan) coupled with an energy dispersive X-ray spectrometer (EDS, JEOL Ltd., Akishima, Japan) operating at $200 \mathrm{kV}$. Particle size distributions (PSD) were determined with a Malvern Zetasizer Nano ZSP (model ZEN5600, Malvern Instruments Ltd., Malvern Worcs, UK) by the dynamic light scattering (DLS) technique. A 12-mm round-aperture-glass cell (PCS8501, Malvern Instruments Ltd., Malvern Worcs, UK) was used for the DLS measurements. One milliliter of methanol dispersion sonicated for $5 \mathrm{~min}$ was added to the cell. The suitable refractive index was chosen for the $\mathrm{CeO}_{2}$ samples and dispersant: 2.2 and 1.33, respectively. The distribution of nanoparticles within the polymer was observed by confocal laser scanning microscopy (CLSM) using a Carl ZEISS microscope (Carl Zeiss, Jena, Germany), LSM 700 model and high resolution scanning electron microscope (HRSEM) using a JEOL JSM-6701-F microscope (JEOL Ltd., Akishima, Japan). The fluorescence intensity measurements were performed using the built-in software ZEN of the LSM 710. The intensity peaks, characteristic of a fluorescence emission signal, were $461 \mathrm{~nm}$ for PMMA and $539 \mathrm{~nm}$ for the $\mathrm{CeO}_{2}$ nanoparticles. The optical properties of the $\mathrm{CeO}_{2}$ nanoparticles were analyzed by diffuse reflectance UV-vis spectroscopy using a Cary 5000 spectrophotometer (Agilent Technologies Inc., Santa Clara, CA, USA) with an Internal Diffuse Reflectance accessory (DR) consisting of a 110 -mm-diameter-integrating sphere. Data were collected at a $600 \mathrm{~nm} / \mathrm{min}$ scan rate with a data interval of $1.0 \mathrm{~nm}$ and signal-averaging time of $0.1 \mathrm{~s}$ in the $700-200 \mathrm{~nm}$ range. The optical transmission of the PMMA/ $\mathrm{CeO}_{2}$ hybrid systems was measured in the $200-1100 \mathrm{~nm}$ wavelength range using the same spectrometer. The thickness of the analyzed samples was about $0.5 \mathrm{~mm}$. TGA studies were carried out using a Simultaneous Thermal Analyser Labsys Evo 1600 (SETARAM Instrumentation, Caluire, France). Samples were placed in aluminum crucibles. An empty aluminum crucible was used as reference. The heating ramp applied to the samples was from 25 to $450{ }^{\circ} \mathrm{C}$ at a constant heating rate of $5{ }^{\circ} \mathrm{C} / \mathrm{min}$ under argon atmosphere. The nanoindentation data were analyzed with the CSM Instruments Nanoindentation Tester (TTX-NHT) with a Berkovich triangular diamond pyramid indenter (CSM Instruments SA, Peseux, Switzerland). Five indents were made in each sample. A loading rate of $15 \mathrm{mN} / \mathrm{min}$ was maintained until reaching a maximum load of $5 \mathrm{mN}$. The load was held at maximum value for $10 \mathrm{~s}$. The hardness $\left(H_{\mathrm{IT}}\right)$, Vickers hardness $\left(H V_{\mathrm{IT}}\right)$, elastic modulus $\left(E_{\mathrm{IT}}\right)$ and creep $\left(C_{\mathrm{IT}}\right)$ were estimated from the initial gradient of the unloading curves using the Oliver and Pharr method [28].

\section{Results and Discussion}

\subsection{Characterization of $\mathrm{CeO}_{2}$ Nanopowders}

\subsubsection{FT-IR Analysis}

The FT-IR spectra of $\mathrm{CeO}_{2}$ nanoparticles thermally treated at different temperatures $(400,600$ and $800{ }^{\circ} \mathrm{C}$ ) are shown in Figure 1a. As a reference, FT-IR results for $\mathrm{CeO}_{2}$ particles dried at $120{ }^{\circ} \mathrm{C}$ and 
thermally-treated at $235{ }^{\circ} \mathrm{C}$ were included in the figure. The spectrum of the $\mathrm{CeO}_{2}$ xerogel $\left(120{ }^{\circ} \mathrm{C}\right)$ shows a broad absorption band located in the region from 3600 to $3000 \mathrm{~cm}^{-1}$ approximately, which corresponds to the $-\mathrm{OH}$ stretching vibration (water or ethanol), while the bands around 1632 and $1503 \mathrm{~cm}^{-1}$ are associated with the $\mathrm{H}_{2} \mathrm{O}$ bending vibration [29], confirming the presence of residual physisorbed water. Moreover, the narrow and sharp band near $1384 \mathrm{~cm}^{-1}$ is attributed to the presence of $\mathrm{NO}_{3}{ }^{-}$groups [30]. As it is evident, the absorption bands mentioned above decrease gradually until disappear with the increasing of treatment temperature. It is also seen that all the $\mathrm{CeO}_{2}$ powders treated at different temperatures show a band in the $750-400 \mathrm{~cm}^{-1}$ region, which is assigned to the $\mathrm{Ce}-\mathrm{O}$ stretching vibration [31,32]. Figure $1 \mathrm{~b}$ shows the FT-IR spectra of the pure PMMA and PMMA/CeO 2 hybrid systems. For pure PMMA, the bands around 2996, 2952 (asymmetric) and $2844 \mathrm{~cm}^{-1}$ (symmetric) are assigned to $\mathrm{C}-\mathrm{H}$ stretching vibrations. The bending vibration bands of the methyl $\left(-\mathrm{CH}_{3}\right)$ group appeared at 1484 and $1436 \mathrm{~cm}^{-1}$ in the FTIR spectra, whereas the deformation mode of the methylene $\left(-\mathrm{CH}_{2}-\right)$ group appeared at $1387 \mathrm{~cm}^{-1}$. In addition, the sharp and intense bands at 1728 and $753 \mathrm{~cm}^{-1}$ are attributed to the stretching and out-of-plane-bending vibrations of the carbonyl $(\mathrm{C}=\mathrm{O})$ group, respectively [33]. The $\mathrm{PMMA} / \mathrm{CeO}_{2}$ hybrid systems show absorption bands that matched well with pure PMMA, indicating a weak interaction between PMMA and $\mathrm{CeO}_{2}$ nanoparticles. Furthermore, bands corresponding to the vibration absorption of $\mathrm{CeO}_{2}$ nanoparticles are not observed owing to the incorporation of a low percentage of nanoparticles. It is worth to notice that to avoid altering the full transparency low percentages of $\mathrm{CeO}_{2}$ were introduced $(0.5$ and $1.0 \mathrm{wt} \%)$.

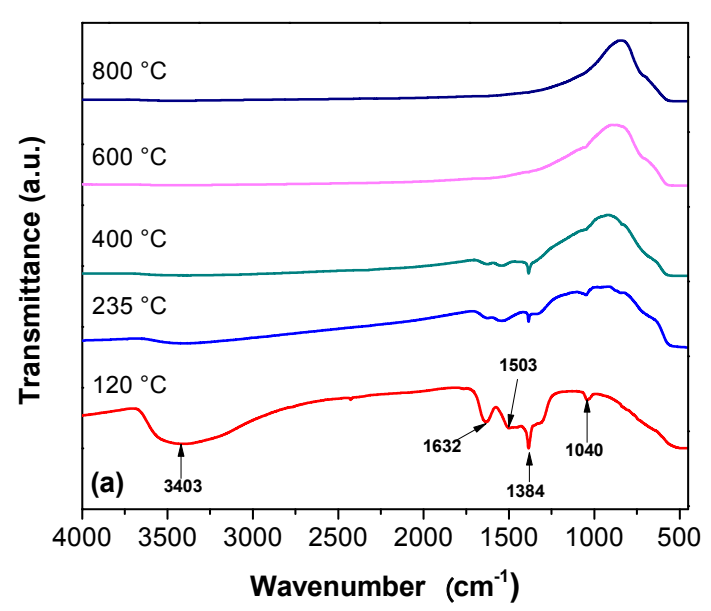

(a)

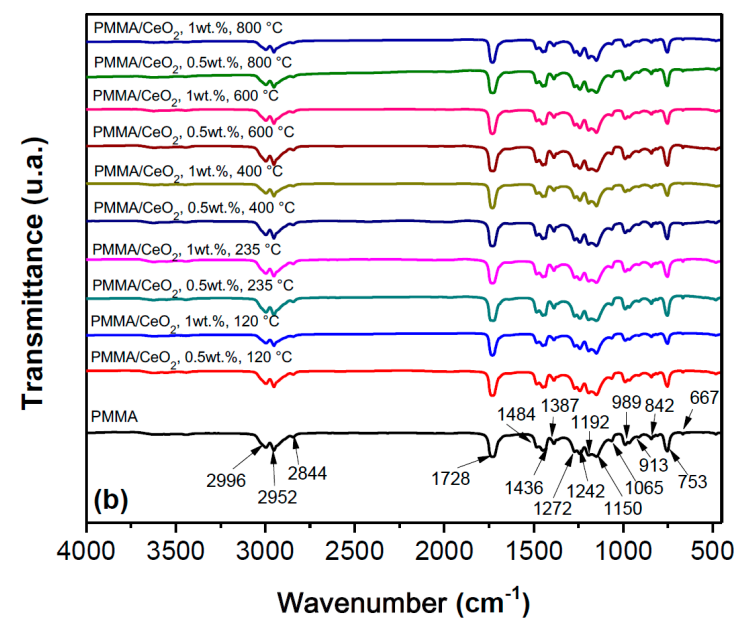

(b)

Figure 1. FT-IR spectra of (a) $\mathrm{CeO}_{2}$ thermally treated at different temperatures and (b) pure PMMA and PMMA/CeO 2 hybrid systems.

\subsubsection{NMR Studies}

Figure 2a shows the ${ }^{1} \mathrm{H}$ NMR spectra of pure PMMA and $\mathrm{PMMA} / \mathrm{CeO}_{2}\left(0.5\right.$ and $\left.1.0 \mathrm{wt} \%, 800{ }^{\circ} \mathrm{C}\right)$ hybrid systems. The peak at $3.60 \mathrm{ppm}$ is related to the methoxy protons, and peaks at the $2.2-1.5 \mathrm{ppm}$ range correspond to the methylene protons of PMMA. The $\alpha$-methyl protons show peaks at 1.22, 1.01 and $0.83 \mathrm{ppm}$, which are attributed to the presence of triads of several tacticities: isotactic $(\mathrm{mm})$, heterotactic $(\mathrm{mr})$ and syndiotactic (rr). On the other hand, it can be observed that the addition of a small amount of 
$\mathrm{CeO}_{2}$ nanoparticles (0.5 and $1.0 \mathrm{wt} \%$ ) to PMMA resulted in a low-field chemical shift of the peak at $1.59 \mathrm{ppm}$ ( $-\mathrm{CH}_{2}-$ protons). This small chemical shift suggests the existence of electrostatic interactions in the interfacial region between PMMA and $\mathrm{CeO}_{2}$ nanoparticles, which is proposed in Figure 3. ${ }^{13} \mathrm{C}$ NMR spectra of PMMA and the hybrid systems with 0.5 and $1.0 \mathrm{wt} \%$ of $\mathrm{CeO}_{2}$ thermally treated at $800{ }^{\circ} \mathrm{C}$ are reported in Figure 2b. The resonance peaks between 22 and $16 \mathrm{ppm}$ are assigned to the methyl group; peaks between 46 and $44 \mathrm{ppm}$ are related to the backbone quaternary carbon; the peak at $51.86 \mathrm{ppm}$ is due to the methoxy group; the peak at $54.47 \mathrm{ppm}$ is associated with the backbone methylene group; and the peaks between 179 and 176 ppm are correlated to the PMMA carbonyl carbon. No modification in the chemical shift is observed with the addition of $\mathrm{CeO}_{2}$ nanoparticles, indicating that no primary chemical bond occurred with the polymer.
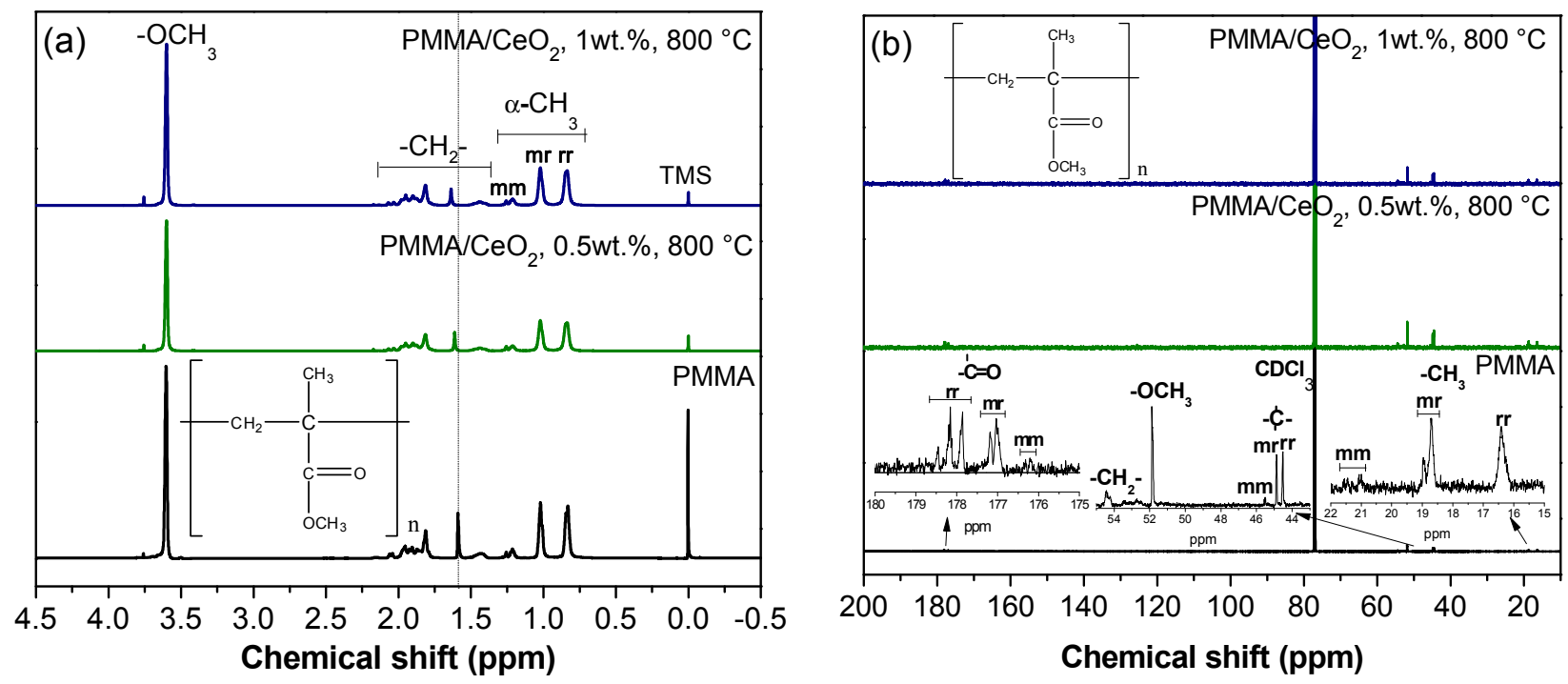

Figure 2. NMR spectra of pure PMMA and $\mathrm{PMMA} / \mathrm{CeO}_{2}$ hybrid systems by (a) ${ }^{1} \mathrm{H} \mathrm{NMR}$ and (b) ${ }^{13} \mathrm{C}$ NMR.

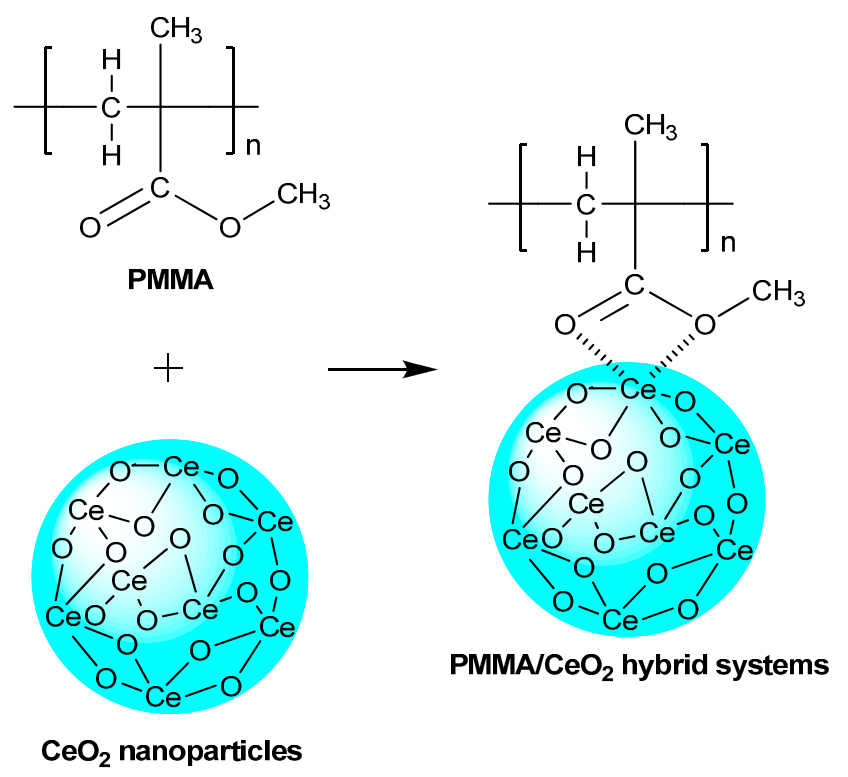

Figure 3. Proposed interaction between the PMMA matrix and $\mathrm{CeO}_{2}$ nanoparticles. 


\subsubsection{Structural and Morphological Characterization}

Figure 4a shows XRD patterns of the $\mathrm{CeO}_{2}$ nanoparticles thermally treated at different temperatures. It can be observed that the $\mathrm{CeO}_{2}$ powders treated at $120{ }^{\circ} \mathrm{C}$ exhibited low intensity broad peaks about $2 \theta=28.5,33.0,47.5$ and $56.3^{\circ}$, which were assigned to the (111), (200), (220) and (311) planes, respectively, and correspond to the cubic fluorite crystal structure (ICDD 81-0792). It is clear that these reflection peaks become sharper and narrower with the increasing temperature up to $800{ }^{\circ} \mathrm{C}$, indicating an increase in the average crystallite size and crystallinity of nanoceria powders. The peaks at $59.0^{\circ}(222)$, $69.3^{\circ}(400), 76.6^{\circ}(331), 79.0^{\circ}(420)$ and $88.4^{\circ}$ (422) also confirms the presence of the cubic phase.
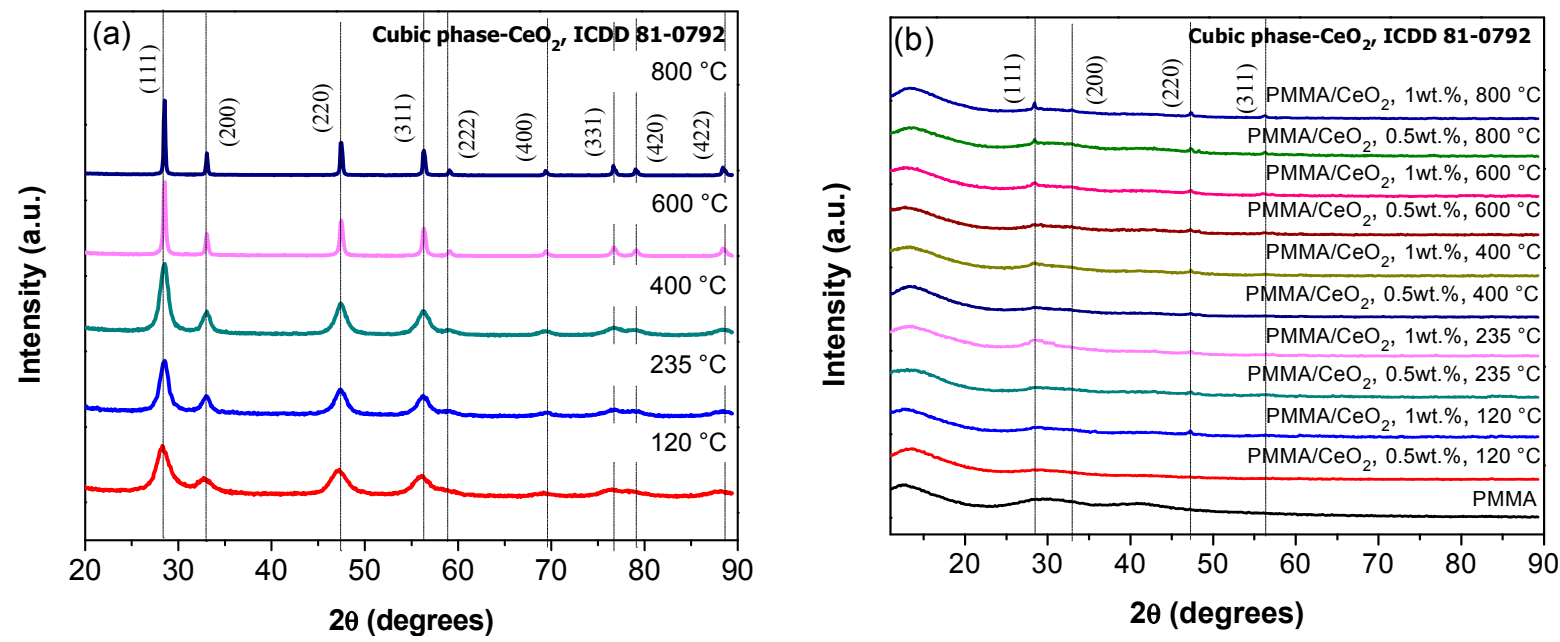

Figure 4. XRD patterns of (a) nanocrystalline $\mathrm{CeO}_{2}$ powders thermally treated at different temperatures and (b) pure PMMA and $\mathrm{PMMA} / \mathrm{CeO}_{2}$ hybrid systems.

The crystallite size $(t)$ of $\mathrm{CeO}_{2}$ was estimated from XRD patterns by applying the full-width at half-maximum $(\beta)$ of the characteristic (111) peak in the Scherrer Equation [34]:

$$
t=\frac{0.9 \lambda}{\beta \cos \theta_{\beta}}
$$

where $\lambda$ is the incident X-ray wavelength (1.54056 $\AA$ ) and $\theta_{\beta}$ is the diffraction angle for the (111) plane. The average $\mathrm{CeO}_{2}$ crystallite diameters determined with the Scherrer Equation were about $5.5 \pm 0.1$, $8.6 \pm 0.2,8.8 \pm 0.1,29.3 \pm 0.7$ and $47.5 \pm 1.1 \mathrm{~nm}$ for $\mathrm{CeO}_{2}$ powders at $120,235,400,600$ and $800{ }^{\circ} \mathrm{C}$, respectively. The crystallite size increased along with the increasing-thermal-treatment temperature due to a typical diffusion effect. Figure $4 \mathrm{~b}$ shows the XRD patterns of the $\mathrm{PMMA} / \mathrm{CeO}_{2}$ hybrid systems. The diffraction pattern of pure PMMA shows a broad diffraction peak at $2 \theta=14.5^{\circ}$ with other two lower intensity signals centered at $2 \theta=30.7$ and $42.1^{\circ}$, as a result of the diffuse scattering of amorphous PMMA [35]. The shape of the first main signal indicates the ordered packing of the polymer chains. The intensity and shape of the second signal are attributed to the effect inside the main chains [36]. The diffraction patterns of all $\mathrm{PMMA} / \mathrm{CeO}_{2}$ hybrid systems show the first two signals observed in the pure PMMA, indicating that neither the presence of the nanoparticles nor the preparation process changes the orientation of the PMMA chains. The PMMA systems with $\mathrm{CeO}_{2}$ thermally treated at $600{ }^{\circ} \mathrm{C}(1.0 \mathrm{wt} \%)$ and $800{ }^{\circ} \mathrm{C}(0.5$ and $1.0 \mathrm{wt} \%)$ display a strong tendency toward an amorphous structure with low-intensity peaks at $2 \theta=28.5,33.0,47.5$ and $56.3^{\circ}$, which corresponds to the fcc structure of $\mathrm{CeO}_{2}$. 
The lattice parameter was calculated from XRD patterns and the results confirmed that except for $120{ }^{\circ} \mathrm{C}$, where a value of $5.4448 \AA$ was obtained, a quite small change in the lattice parameter was observed with the thermal treatment: $5.4192 \AA\left(235^{\circ} \mathrm{C}\right), 5.4187 \AA\left(400{ }^{\circ} \mathrm{C}\right), 5.4107 \AA\left(600{ }^{\circ} \mathrm{C}\right)$ and $5.4127 \AA\left(800{ }^{\circ} \mathrm{C}\right)$. It was determined that the lattice parameter showed a trend of expansion with the annealing temperature but the changing extent is moderately limited. The lattice distortion rate $(\Delta a / a)$ was estimated to be between $0.60 \%$ and $0.013 \%$. The highest distortion was obtained at $120{ }^{\circ} \mathrm{C}$ and is undoubtedly due to this temperature that some organic compounds or water or both can be still partially bonded with cerium powders. The formation of nanoceria powders by sol-gel contains complicated reactions; in the first instance, they began to nucleate into $\mathrm{Ce}(\mathrm{OH})_{3}$ form, so the supplied energy during the sol-gel process and subsequent heat treatment must be enough for the complete conversion to $\mathrm{Ce}(\mathrm{OH})_{4}$ nuclei and thereafter into $\mathrm{CeO}_{2}$ nuclei via dehydration and subsequent growth of highly crystallized nanoceria.

TEM images of $\mathrm{CeO}_{2}$ in bright field mode with their corresponding selected area electron diffraction pattern (SAEDP) are shown in Figure 5. The $\mathrm{CeO}_{2}$ nanopowders exhibit a heterogeneous size and non-uniform shape with a high agglomeration degree. Indeed, a higher treatment temperature seems to increase the particle size. The images show that the $\mathrm{CeO}_{2}$ powders thermally treated at $120{ }^{\circ} \mathrm{C}$ are constituted of aggregates with sizes between 0.1 and $0.2 \mu \mathrm{m}$ and composed by crystals of about $1-5 \mathrm{~nm}$ in diameter. $\mathrm{CeO}_{2}$ thermally treated at $235^{\circ} \mathrm{C}$ shows aggregates between 0.2 and $0.3 \mu \mathrm{m}$ with irregular smaller crystals of about $4-12 \mathrm{~nm}$, while $\mathrm{CeO}_{2}$ thermally treated at $400{ }^{\circ} \mathrm{C}$ consists of aggregates formed of nanocrystals with an average size of 5-13 nm. When the heat treatment of $\mathrm{CeO}_{2}$ is increased to $600{ }^{\circ} \mathrm{C}$, the resulting samples are $0.45-0.35 \mu \mathrm{m}$ aggregates with semispherical nanocrystal sizes around $4-22 \mathrm{~nm}$. Likewise, $\mathrm{CeO}_{2}$ thermally treated at $800{ }^{\circ} \mathrm{C}$ shows aggregates between $0.52-0.75 \mu \mathrm{m}$ constituted by nanocrystals of about $20-80 \mathrm{~nm}$. The SAEDPs of $\mathrm{CeO}_{2}$ thermally treated at different temperatures $\left(120,235,400,600\right.$ and $\left.800{ }^{\circ} \mathrm{C}\right)$ show concentric rings, which also indicate the polycrystalline nature of the powder and that the crystallite size is on the nanoscale. The SAEDPs were indexed according to the ICDD card of face-centered cubic phase of $\mathrm{CeO}_{2}$. The mean crystal size values and the diffraction rings of SAED obtained in TEM images for $\mathrm{CeO}_{2}$ matched well with XRD results.

From measurements of dynamic light scattering, different particle diameter moments (number-average diameter $D_{\mathrm{n}}$; weight-average diameter $D_{\mathrm{w}}$ and z-average diameter $D_{\mathrm{z}}$ ) were calculated using Equations (2-4), and the polydispersity index (PDI) was determined using Equation (5):

$$
\begin{gathered}
D_{n}=\frac{\sum n_{i} D_{i}}{\sum n_{i}} \\
D_{w}=\frac{\sum n_{i} D_{i}^{4}}{\sum n_{i} D_{i}^{3}} \\
D_{z}=\frac{\sum n_{i} D_{i}^{6}}{\sum n_{i} D_{i}^{5}} \\
P D I=\frac{D_{w}}{D_{n}}
\end{gathered}
$$

where $n_{i}$ is the number of $\mathrm{CeO}_{2}$ nanoparticles with diameter $D_{i}$. 

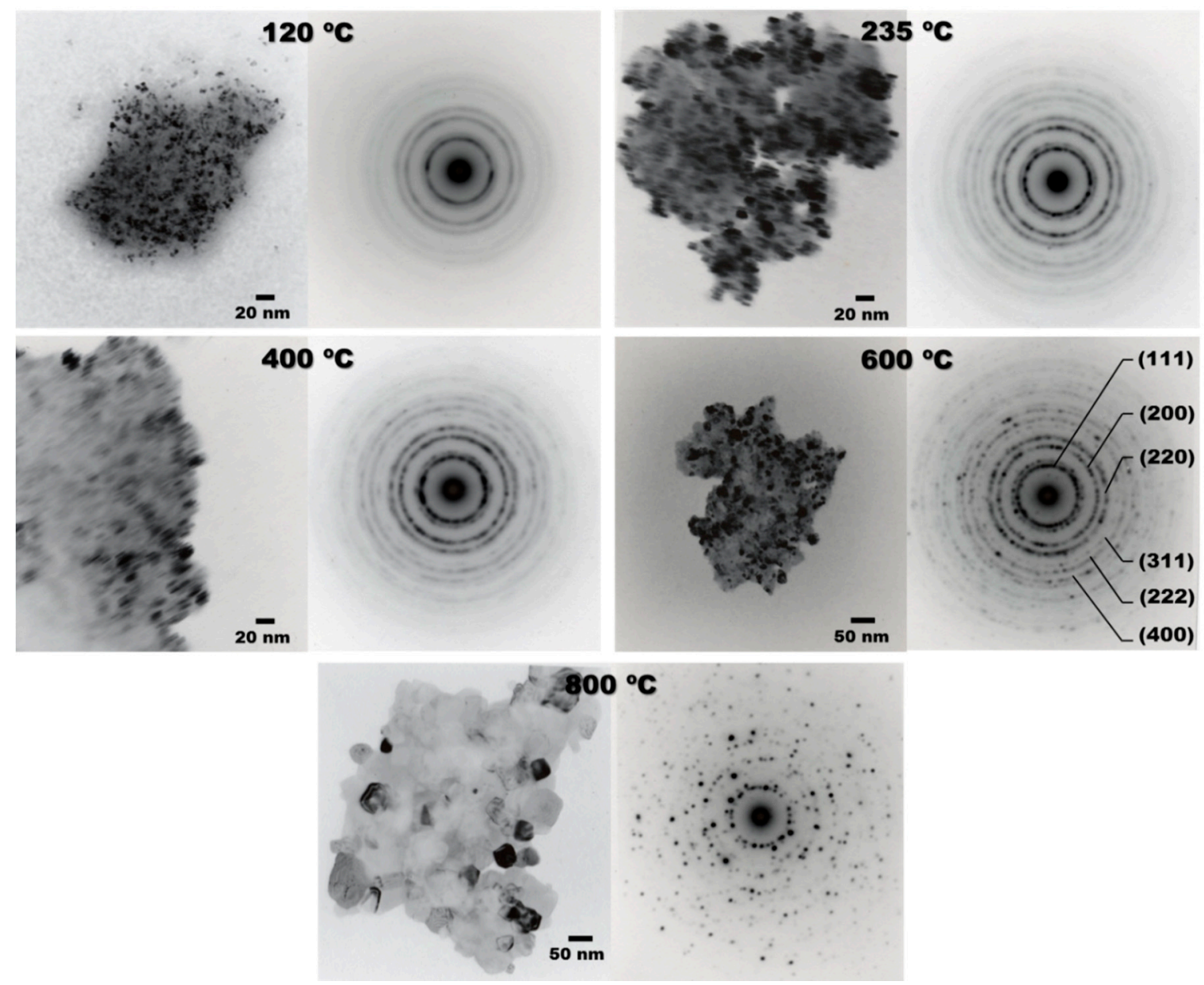

Figure 5. TEM images and SAEDPs of nanocrystalline $\mathrm{CeO}_{2}$ powders thermally treated at different temperatures.

The particle size distributions (PSDs) for the samples are shown in Figure 6, whereas the obtained average particle size and calculated polydispersity index (PDI) are shown in Table 1. From these data, the $\mathrm{CeO}_{2}$ particle size was increased as the temperature varied from 120 to $400{ }^{\circ} \mathrm{C}$. After this temperature, a decrease in the particle size was observed $\left(600\right.$ and $\left.800{ }^{\circ} \mathrm{C}\right)$. It is noteworthy to mention that the particle size distribution can be influenced by sonification and dispersant agent [37]. Furthermore, the $\mathrm{CeO}_{2}$ powders have different particle sizes and therefore they can be considered as polydispersed systems (PDI > 1). In general, these results confirm the presence of agglomerated nanoparticles due to Van der Waals forces and their high surface energy. 

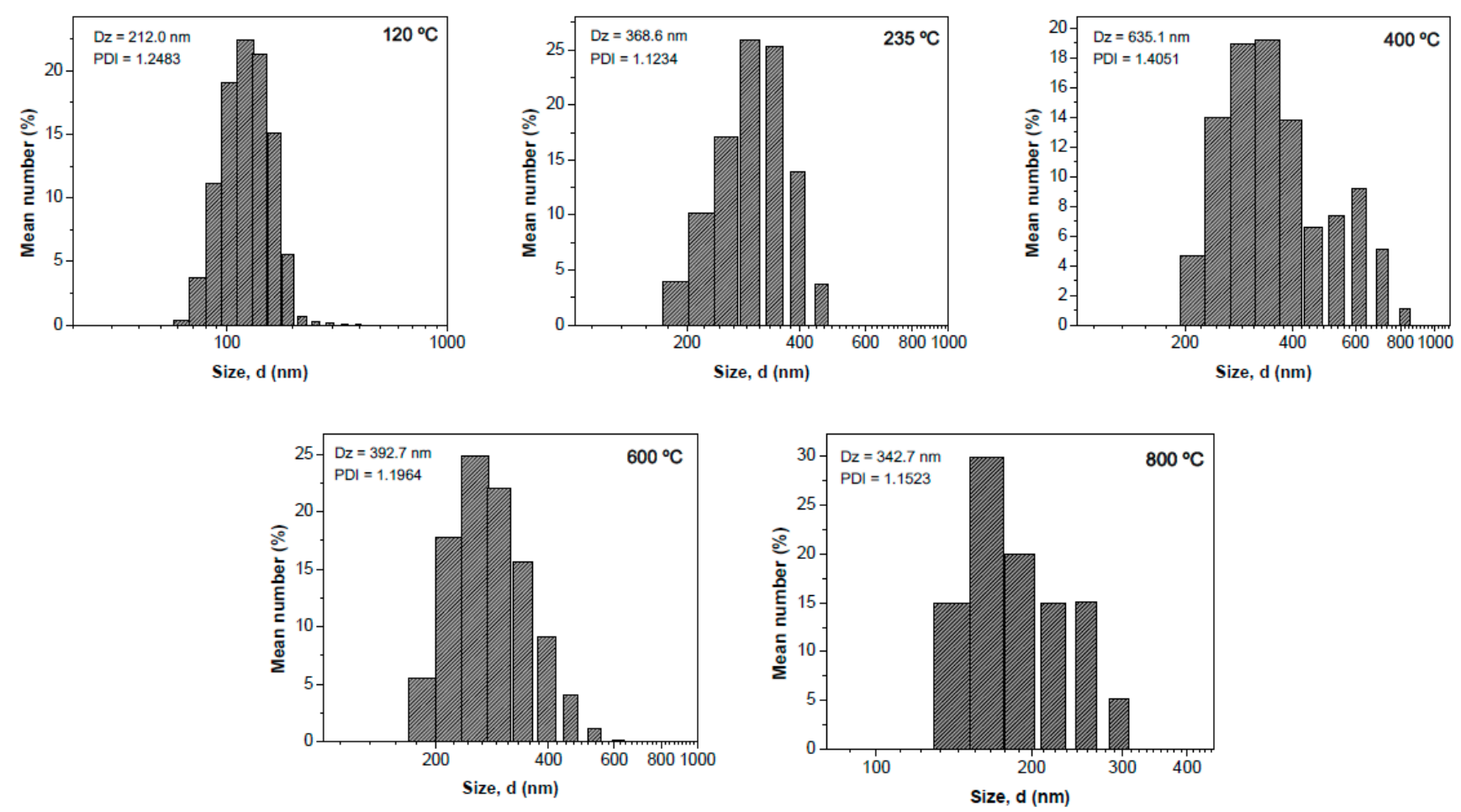

Figure 6. Size distribution of $\mathrm{CeO}_{2}$ thermally treated at different temperatures.

Table 1. Particle size distribution of the as-prepared $\mathrm{CeO}_{2}$ powders.

\begin{tabular}{|c|c|c|c|c|c|c|c|c|c|}
\hline \multicolumn{2}{|c|}{$\mathrm{CeO}_{2} \mathrm{120}^{\circ} \mathrm{C}$} & \multicolumn{2}{|c|}{$\mathrm{CeO}_{2} 235^{\circ} \mathrm{C}$} & \multicolumn{2}{|c|}{$\mathrm{CeO}_{2} 400{ }^{\circ} \mathrm{C}$} & \multicolumn{2}{|c|}{$\mathrm{CeO}_{2} 600{ }^{\circ} \mathrm{C}$} & \multicolumn{2}{|c|}{$\mathrm{CeO}_{2} 800{ }^{\circ} \mathrm{C}$} \\
\hline $\begin{array}{l}\text { Size } \\
d, \mathrm{~nm}\end{array}$ & $\begin{array}{c}\text { Mean } \\
\text { number \% }\end{array}$ & $\begin{array}{c}\text { Size } \\
d, \mathrm{~nm}\end{array}$ & $\begin{array}{c}\text { Mean } \\
\text { number \% }\end{array}$ & $\begin{array}{c}\text { Size } \\
d, \mathrm{~nm}\end{array}$ & $\begin{array}{c}\text { Mean } \\
\text { number \% }\end{array}$ & $\begin{array}{c}\text { Size } \\
d, \mathrm{~nm}\end{array}$ & $\begin{array}{c}\text { Mean } \\
\text { number \% }\end{array}$ & $\begin{array}{c}\text { Size } \\
d, \mathrm{~nm}\end{array}$ & $\begin{array}{c}\text { Mean } \\
\text { number \% }\end{array}$ \\
\hline 68.06 & 0.4 & 190.1 & 3.9 & 220.2 & 4.7 & 190.1 & 5.5 & 141.8 & 14.9 \\
\hline 78.82 & 3.7 & 220.2 & 10.2 & 255.0 & 14.0 & 220.2 & 17.8 & 164.2 & 29.9 \\
\hline 91.28 & 11.1 & 255.0 & 17.1 & 295.3 & 18.9 & 255.0 & 24.8 & 190.1 & 20.0 \\
\hline 105.7 & 19.0 & 295.3 & 25.9 & 342.0 & 19.2 & 295.3 & 22.0 & 220.2 & 15.0 \\
\hline 122.4 & 22.4 & 342.0 & 25.3 & 396.1 & 13.8 & 342.0 & 15.6 & 255.0 & 15.1 \\
\hline 141.8 & 21.3 & 396.1 & 13.9 & 458.7 & 6.6 & 396.1 & 9.1 & 295.3 & 5.1 \\
\hline 164.2 & 15.1 & 458.7 & 3.7 & 531.2 & 7.4 & 458.7 & 4 & - & - \\
\hline 190.1 & 5.6 & - & - & 615.1 & 9.2 & 531.2 & 1.1 & - & - \\
\hline 220.2 & 0.7 & - & - & 712.4 & 5.1 & 615.1 & 0.1 & - & - \\
\hline 255.0 & 0.3 & - & - & 825.0 & 1.1 & - & - & - & - \\
\hline 295.3 & 0.2 & - & - & - & - & - & - & - & - \\
\hline 342.0 & 0.1 & - & - & - & - & - & - & - & - \\
\hline 396.1 & 0.1 & - & - & - & - & - & - & - & - \\
\hline \multicolumn{2}{|c|}{$D_{\mathrm{z}}=212 \mathrm{~nm}$} & \multicolumn{2}{|c|}{$D_{\mathrm{z}}=368.6 \mathrm{~nm}$} & \multicolumn{2}{|c|}{$D_{\mathrm{z}}=635.1 \mathrm{~nm}$} & \multicolumn{2}{|c|}{$D_{\mathrm{z}}=392.7 \mathrm{~nm}$} & \multicolumn{2}{|c|}{$D_{\mathrm{z}}=242.7 \mathrm{~nm}$} \\
\hline \multicolumn{2}{|c|}{$\begin{array}{l}\text { Polydispersity } \\
\text { index }=1.2483\end{array}$} & \multicolumn{2}{|c|}{$\begin{array}{l}\text { Polydispersity } \\
\text { index }=1.1234\end{array}$} & \multicolumn{2}{|c|}{$\begin{array}{l}\text { Polydispersity } \\
\text { index }=1.4051\end{array}$} & \multicolumn{2}{|c|}{$\begin{array}{l}\text { Polydispersity } \\
\text { index }=1.1964\end{array}$} & \multicolumn{2}{|c|}{$\begin{array}{l}\text { Polydispersity } \\
\text { index }=1.1523\end{array}$} \\
\hline
\end{tabular}




\subsection{Characterization of PMMA/Ce $\mathrm{O}_{2}$ Hybrid Materials}

\subsubsection{Dispersion Analysis}

Dispersion is the key factor that determines quality and properties of hybrid compounds [38]. During the dispersion process two kinds of interaction can occur: (i) polymer filler interaction, adhesion of the polymer to the surface of the particles; and (ii) filler-filler interaction, where the particles interact to form aggregates. Figure 7 shows the 3D images revealing the $\mathrm{CeO}_{2}$ nanoparticles' location within the PMMA. In these images, it can be observed that in all the $\mathrm{PMMA} / \mathrm{CeO}_{2}$ hybrid systems the nanoparticles tend to form agglomerates of different sizes and semispherical morphologies. According to Yang et al., the nanoparticles tend to form aggregates to reduce the surface energy due to their high surface energy and small size [39]. It can also be observed that the $\mathrm{CeO}_{2}$ nanoparticles thermally treated at 120, 235 and $400{ }^{\circ} \mathrm{C}$ show a uniform distribution within the PMMA matrix. In the $\mathrm{PMMA} / \mathrm{CeO}_{2}$ hybrid systems with nanoparticles thermally treated at 600 and $800{ }^{\circ} \mathrm{C}$, a small quantity of nanoparticles can be seen because the fluorescence intensity decreases with the increasing crystal size. However, these last systems also show a uniform dispersion, which is a relevant aspect for increasing the thermal stability of the $\mathrm{PMMA} / \mathrm{CeO}_{2}$ hybrid systems.

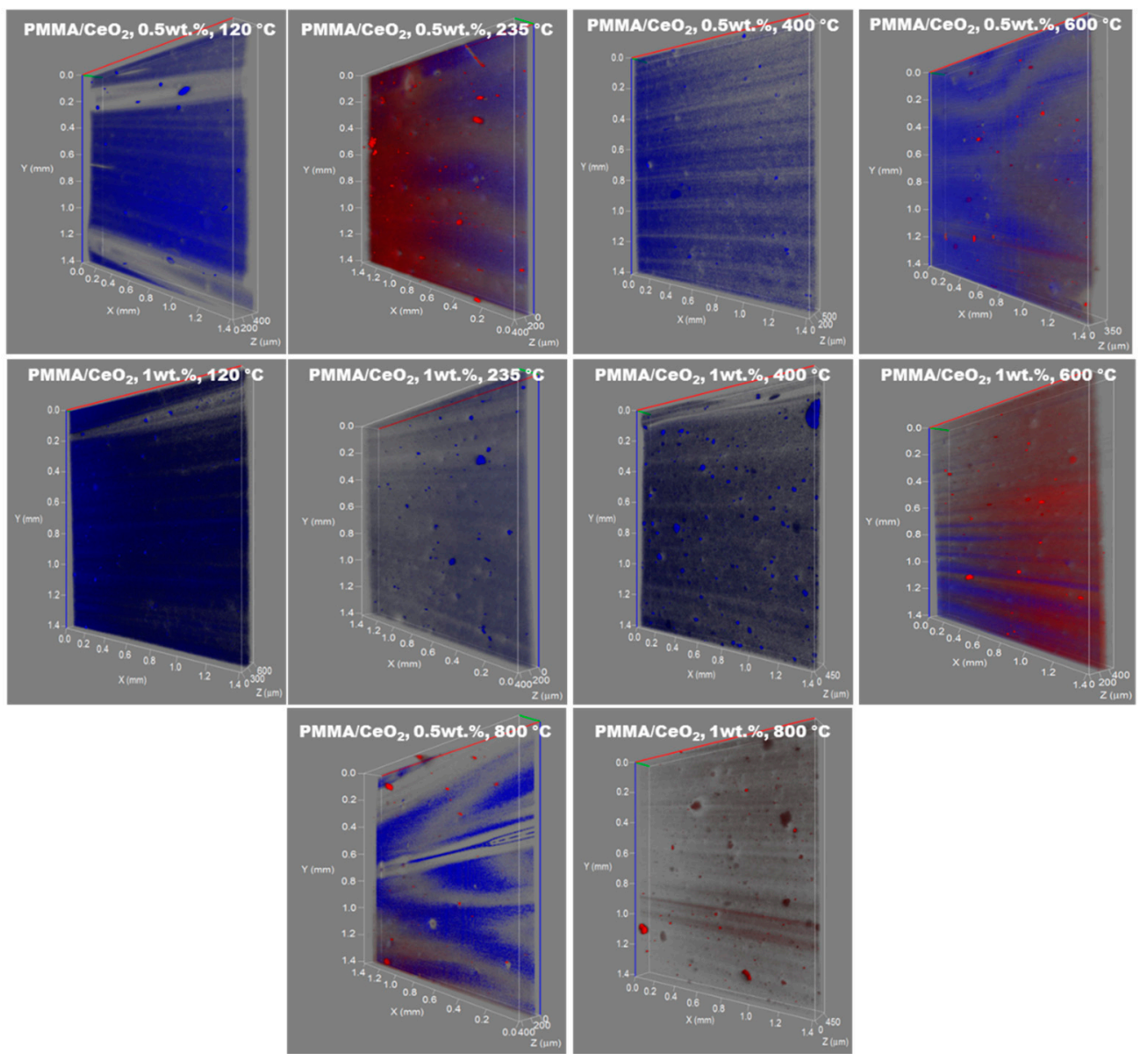

Figure 7. 3D CLSM representations of $\mathrm{PMMA} / \mathrm{CeO}_{2}$ hybrid systems.

To confirm the homogeneous distribution of $\mathrm{CeO}_{2}$ nanoparticles into the polymer matrix, SEM observations of $\mathrm{PMMA} / \mathrm{CeO}_{2}$ cross sections were analyzed for $\mathrm{CeO}_{2}$ powders sintered at 400, 600 and 
$800{ }^{\circ} \mathrm{C}$ (Figure 8a-c). The samples were analyzed at different magnifications using both secondary electrons (SE) and backscattered electrons (BSE). The present morphology confirms that even with the tendency to form some aggregates with a very variable size, the shear stress during melt mixing separate the $\mathrm{CeO}_{2}$ nanoparticles to obtain a good dispersion with an interaction type (i) throughout hydrodynamic forces; in such a case, the effectiveness is also distributed in the entire sample. SEM micrographs reveal that PMMA incorporates semispherical $\mathrm{CeO}_{2}$ domains, which are an ideal physical form to improve polymer properties.
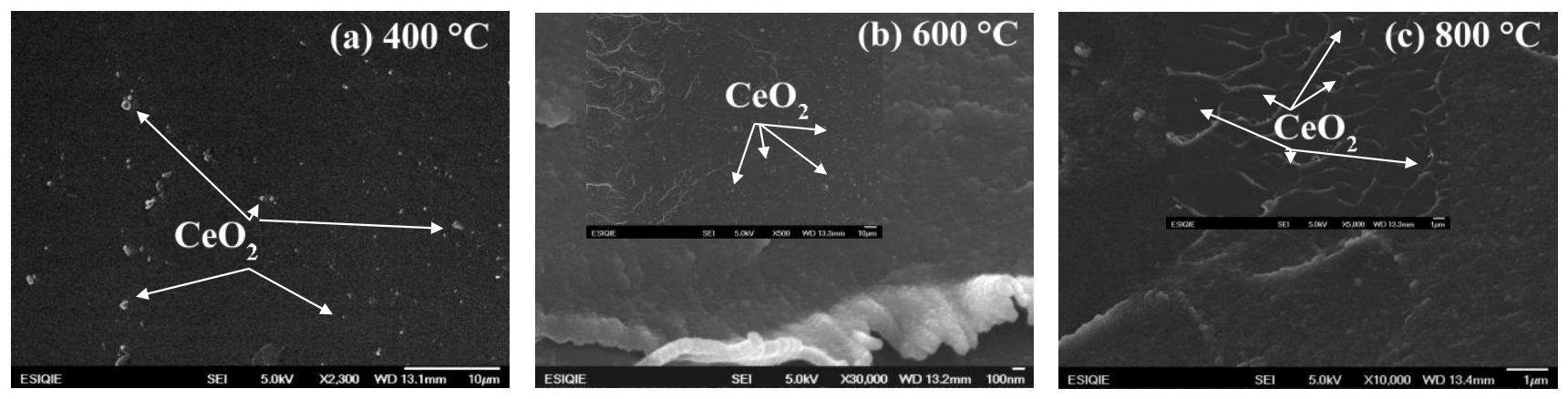

Figure 8. Cross-section SEM micrographs of PMMA with $1.0 \mathrm{wt} \%$ of $\mathrm{CeO}_{2}$ nanoparticles sintered at (a) $400{ }^{\circ} \mathrm{C}$; (b) $600{ }^{\circ} \mathrm{C}$ and (c) $800{ }^{\circ} \mathrm{C}$.

\subsubsection{Optical Properties}

The Kulbeka-Munk Equation was used to obtain the accurate band gap energy of $\mathrm{CeO}_{2}$ nanoparticles $\left(E_{\mathrm{g}}\right)$. The reflectance data were converted to the absorption coefficient $F\left(R_{\infty}\right)$ values using the following equation:

$$
F\left(R_{\infty}\right)=\frac{\left(1-R_{\infty}\right)^{2}}{2 R_{\infty}}
$$

where $R_{\infty}$ is the diffused reflectance at a given wavelength of an infinitely thick sample and

$$
E(e V)=\frac{h C}{\lambda}
$$

where $\mathrm{h}$ is Planck's constant $\left(6.626 \times 10^{-34} \mathrm{~J} \mathrm{~s}\right), C$ is the light speed $\left(3.0 \times 10^{8} \mathrm{~ms}^{-1}\right)$ and $\lambda$ is the wavelength $(\mathrm{nm})[40]$. The relationship between $\left(F\left(R_{\infty}\right) h v\right)^{2}$ and the photon energy of $\mathrm{CeO}_{2}$ nanoparticles thermally treated at different temperatures are shown in Figure 9. The indirect band gap energy $\left(E_{\mathrm{g}}\right)$ was obtained from the intersection of the extrapolated linear portion. The $E_{\mathrm{g}}$ values of the $\mathrm{CeO}_{2}$ powders thermally treated at $120,235,400,600$ and $800{ }^{\circ} \mathrm{C}$ were $3.40 \pm 0.01,3.34 \pm 0.02,3.33 \pm 0.03,3.40 \pm 0.02$ and $3.44 \pm 0.01$, respectively. It reveals that the $E_{\mathrm{g}}$ decreases with increasing the treatment temperature up to $400{ }^{\circ} \mathrm{C}$ and then a slight increase is observed with the powders treated at 600 and $800{ }^{\circ} \mathrm{C}$. In addition, in the inset, $\left(F\left(R_{\infty}\right) h v\right)^{2}$ vs $\lambda$ curves, it was found that all the $\mathrm{CeO}_{2}$ powders show a strong absorption band at 210-350 $\mathrm{nm}$ in the UV range originated from the charge-transfer between the $\mathrm{O} 2 \mathrm{p}$ and $\mathrm{Ce} 4 \mathrm{f}$ states in $\mathrm{O}^{2-}$ and $\mathrm{Ce}^{4+}$ [41]. UV shielding materials are generally expected to absorb UV light at less than $400 \mathrm{~nm}$ wavelengths, as obtained for the $\mathrm{CeO}_{2}$ nanoparticles thermally treated at different temperatures.

Transmission spectra in the UV-Vis region for pure PMMA and PMMA samples with 0.5 and 1.0 wt \% $\mathrm{CeO}_{2}$ at different thermal-treatment temperatures are shown in Figure 10. It can be seen that the UV-Vis 
absorption of the PMMA/CeO ${ }_{2}$ nanocomposites increased with the $\mathrm{CeO}_{2}$ nanoparticle content in the nanocomposite. The PMMA/CeO $\mathrm{C}_{2}$ hybrid system with nanoparticles thermally treated at 120 and $235^{\circ} \mathrm{C}$ shows similar behavior with a transmittance decrease of about 22 and 40 percent $(0.5$ and $1.0 \mathrm{wt} \%)$ in comparison with pure PMMA. This strong decrease is primarily attributed to the organic matter present in $\mathrm{CeO}_{2}$ as it was observed by FTIR, as a result of the low thermal-treatment temperatures. On the other hand, the $\mathrm{PMMA} / \mathrm{CeO}_{2}$ hybrid systems with 0.5 and $1.0 \mathrm{wt} \% \mathrm{CeO}_{2}$ thermally treated at $400{ }^{\circ} \mathrm{C}$ display a transmittance reduction of approximately 7-15 percent in comparison with pure PMMA, which are the most transparent systems. It can be noticed that of all the hybrid systems, nanocomposites with 0.5 wt $\%$ of $\mathrm{CeO}_{2}$ at $400{ }^{\circ} \mathrm{C}$ showed the highest percentage of transmittance, whereas the PMMA with 1.0 wt $\%$ of $\mathrm{CeO}_{2}$ treated at high temperatures $\left(600\right.$ and $\left.800{ }^{\circ} \mathrm{C}\right)$ showed lower values in comparison with systems formed by $\mathrm{CeO}_{2}$ at $400{ }^{\circ} \mathrm{C}$. The aforesaid is related to the formations of small crystalline domains embedded in the amorphous PMMA as well as crystal size growth with sintered temperature. Figure 11 shows photographs of these films, where it is evident that even the presence of a small percentage of $\mathrm{CeO}_{2}$ leads opacity or turbidity due to the fact that the agglomerated $\mathrm{CeO}_{2}$ nanoparticles act as a strong scattering center. This point also suggests that the UV shielding properties of the hybrid films are mainly due to the scattering of these agglomerates in the film. As it was mentioned, the particles agglomeration enhanced with the thermal treatment and crystallite size; however, the aggregates are homogeneously distributed within the polymeric matrix.
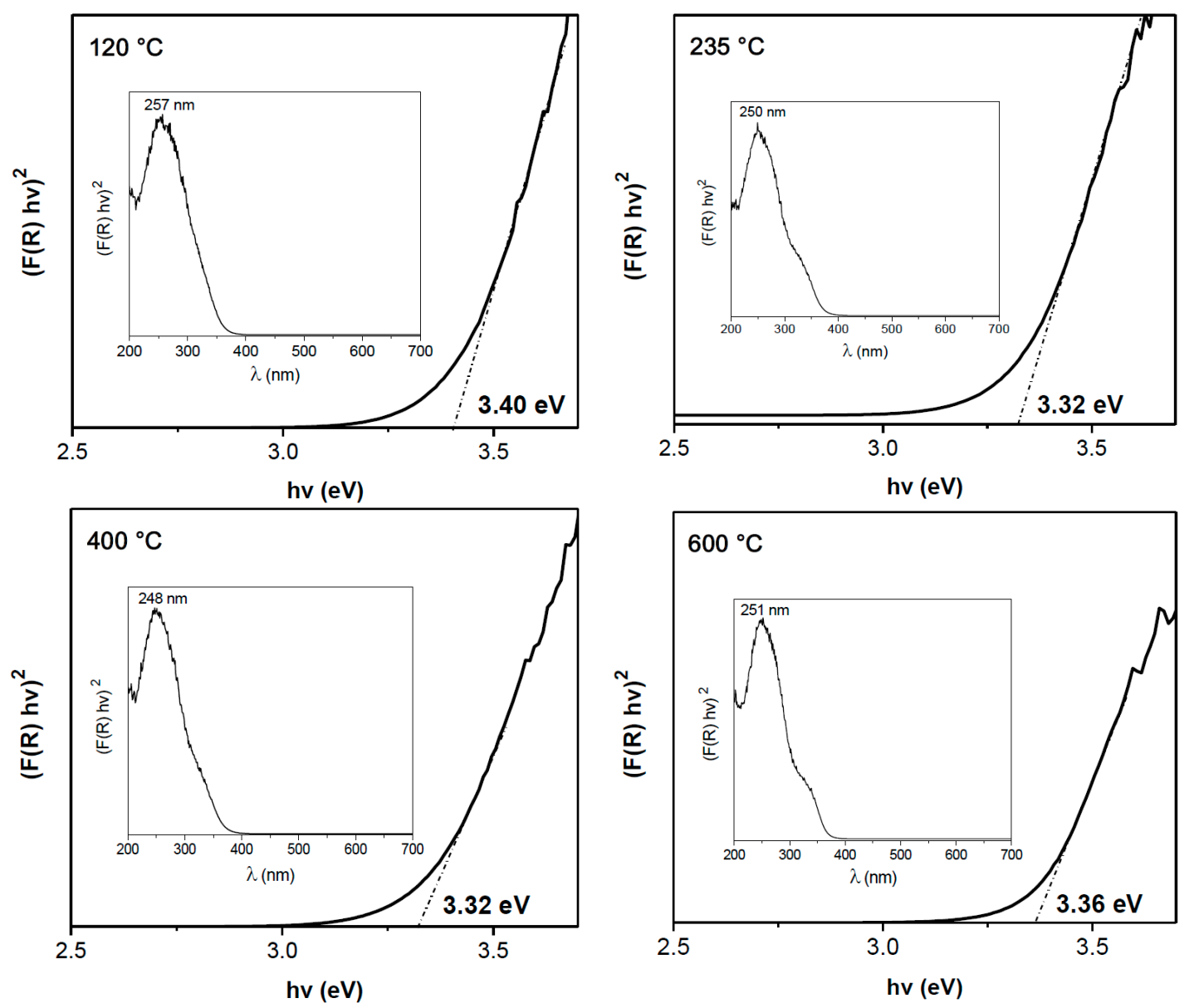

Figure 9. Cont. 


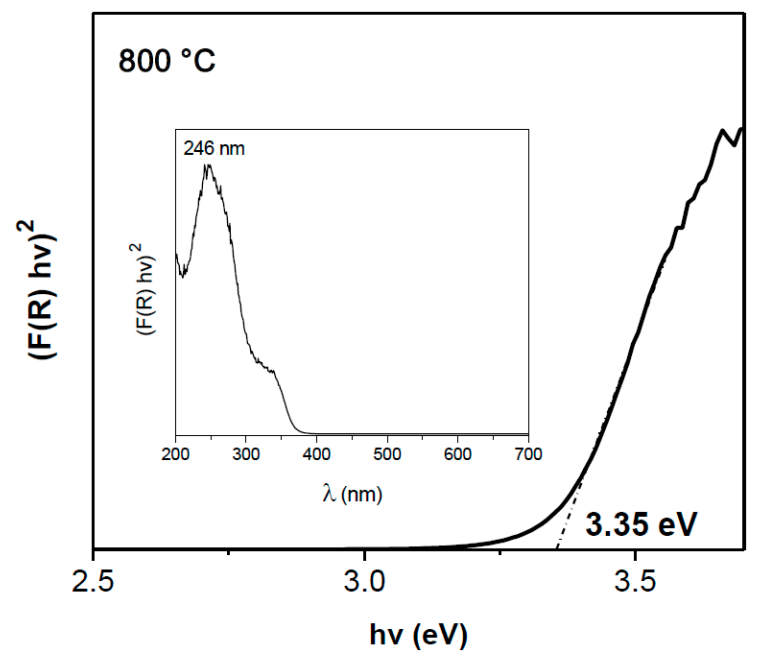

Figure 9. Kubelka-Munk modified spectra and their equivalence in $\mathrm{h} v$ vs $\lambda$ (insert) of $\mathrm{CeO}_{2}$ powders thermally treated at different temperatures.

Likewise, spectra of pure PMMA and $\mathrm{PMMA} / \mathrm{CeO}_{2}$ nanocomposites show an absorption band at about $272 \mathrm{~nm}$, which is attributed to the $n-\pi^{*}$ transition of the $\mathrm{C}=\mathrm{O}$ group in the PMMA [42]. This band is attenuated with the incorporation of $\mathrm{CeO}_{2}$ treated at different temperatures causing a significant decrease in transmittance in the 250-360 nm range, which can be associated with the band-gap absorption of $\mathrm{CeO}_{2}$. In general, the synthetic polymers are susceptible to degradation by $\mathrm{UV}$ and visible light; specifically, the photodegradation of PMMA took place by irradiation between 260 and $300 \mathrm{~nm}$ [43]. The transmitting efficiency of the $\mathrm{PMMA} / \mathrm{CeO}_{2}$ hybrid systems in the $\mathrm{UV}$ band up to $350 \mathrm{~nm}$ is approximately zero, demonstrating that such hybrid systems are a good option for exterior applications.

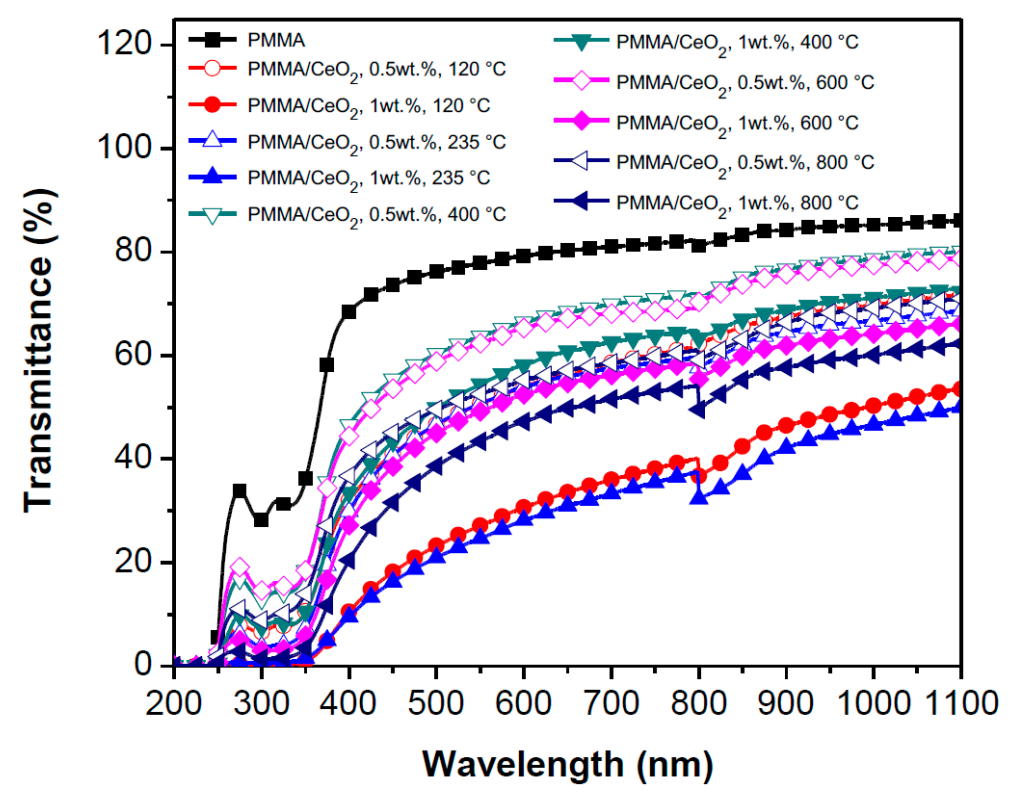

Figure 10. UV-Vis spectra of pure PMMA and $\mathrm{PMMA} / \mathrm{CeO}_{2}$ hybrid systems. 


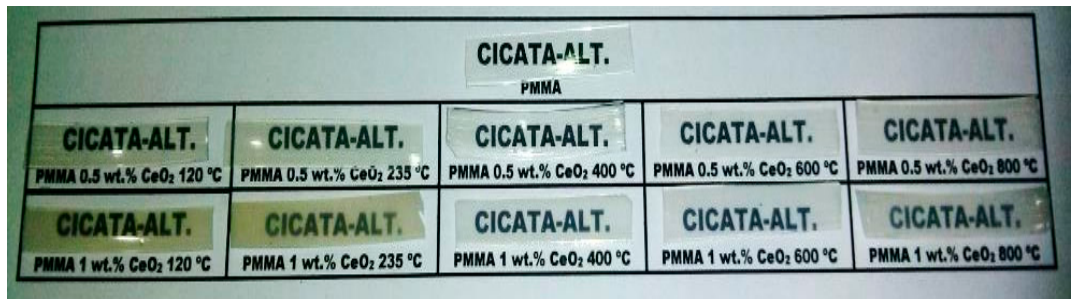

Figure 11. Photographs of the pure PMMA and $\mathrm{PMMA} / \mathrm{CeO}_{2}$ hybrid systems.

\subsubsection{Thermal Studies}

Different studies have been performed on the different steps involved in the thermal degradation of PMMA. According to Kashiwagi et al. [44], the bond dissociation energy of $\mathrm{H}-\mathrm{H}$ linkages is estimated to be less than that of the $\mathrm{C}-\mathrm{C}$ backbone bond due to the large steric hindrance and inductive effect of vicinal ester groups. The first degradation step $\left(155-220{ }^{\circ} \mathrm{C}\right)$ is initiated by scissions of head-to-head linkages $(\mathrm{H}-\mathrm{H})$. Likewise, PMMA chains having unsaturated end group are less thermally stable than those with saturated end groups. Therefore, the second step $\left(230-300{ }^{\circ} \mathrm{C}\right)$ is initiated by scissions at unsaturated ends involving a hemolytic scission $\beta$ to the vinyl group and the last step $\left(>30{ }^{\circ} \mathrm{C}\right)$ is initiated by random scission within the main polymer chain. Typical TGA and derivative thermogravimetry (DTG) results on PMMA and PMMA/CeO ${ }_{2}$ hybrid materials degraded under argon atmosphere are shown in Figure 12. In Figure 12a, it can be observed that the pure PMMA shows appreciable weight loss at around $240{ }^{\circ} \mathrm{C}$, while the PMMA/ $\mathrm{CeO}_{2}$ nanocomposites show detectable weight loss at $320^{\circ} \mathrm{C}$. It is also evident that the stability of the nanocomposites is enhanced with the thermal treatment applied to $\mathrm{CeO}_{2}$ nanopowders. Particularly, $\mathrm{PMMA} / \mathrm{CeO}_{2}$ hybrid systems with $0.5-1.0 \mathrm{wt} \% \mathrm{CeO}_{2}$ thermally treated at $120{ }^{\circ} \mathrm{C}$ began to show a weight loss below $250{ }^{\circ} \mathrm{C}$. Underneath to $200{ }^{\circ} \mathrm{C}$ the weight loss is commonly referred to removal of water and organic components from the structure, whereas between 200 and $300{ }^{\circ} \mathrm{C}$ corresponds to nitrates decomposition and carbonization of organic parts of the precursor [45]. Furthermore, a single broad loss, extending from 320 to about $450{ }^{\circ} \mathrm{C}$, is observed for all nanocomposites. From Figure 12a, data were taken for the onset temperature at which $10 \%\left(T_{0.1}\right)$ and $50 \%\left(T_{0.5}\right)$ degradation occurs and the corresponding temperature difference $(\Delta T)$ between the onset temperatures of hybrid systems and PMMA (Table 2). Evidently, the onset degradation temperatures of $\mathrm{PMMA} / \mathrm{CeO}_{2}$ hybrid systems shift to higher temperatures in comparison with that of pure PMMA, independently of the $\mathrm{CeO}_{2}$ thermal-treatment temperature and content, indicating that the $\mathrm{CeO}_{2}$ nanocrystals can significantly improve the thermal stability of the polymer. As seen in Figure 12b, it is confirmed that the temperature at maximum degradation rate increases largely from $273{ }^{\circ} \mathrm{C}$ for pure PMMA to $365{ }^{\circ} \mathrm{C}$ for all the PMMA/CeO $\mathrm{C}_{2}$ nanocomposites. Although the $\mathrm{CeO}_{2}$ nanoparticles are agglomerated within the PMMA, their homogeneous presence play an important role enhancing the thermal stability of PMMA as a result of the mobility restriction of polymer chains near their interfaces due to the steric hindrance, hindering the out-diffusion of the volatile decomposition products $[46,47]$. 

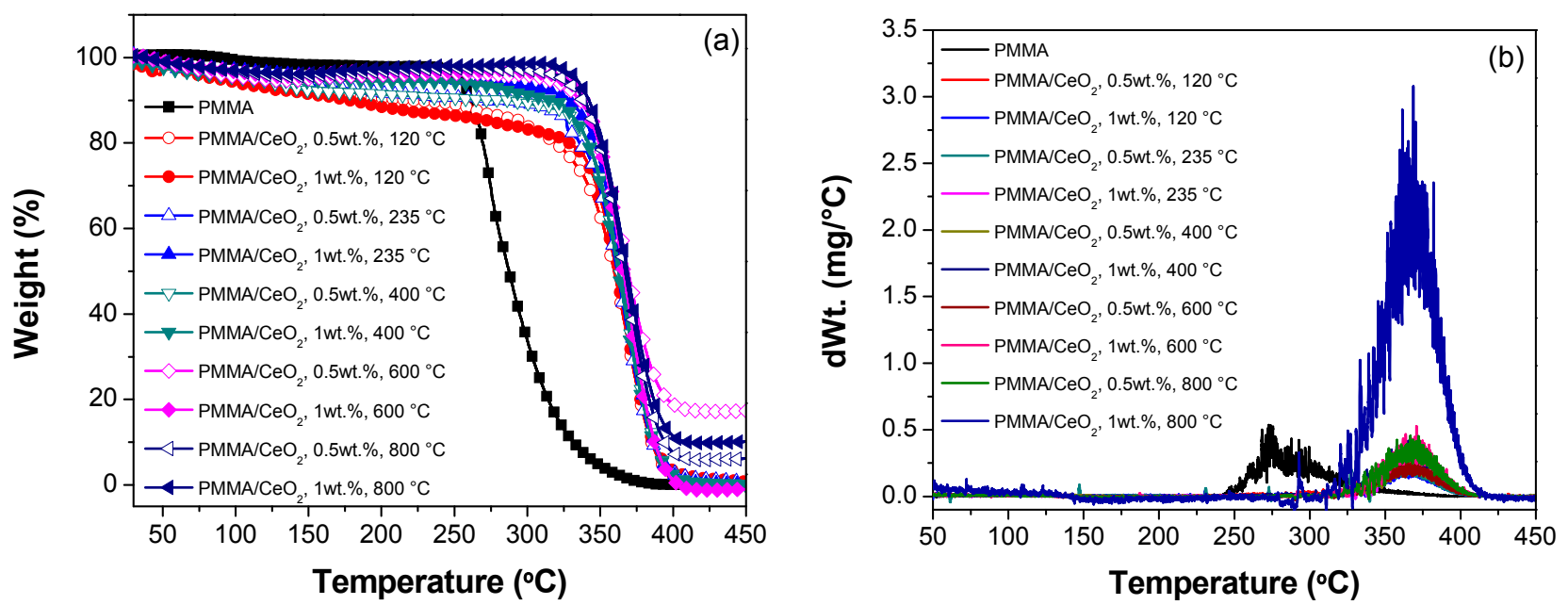

Figure 12. (a) TGA and (b) DTG curves of pure PMMA and $\mathrm{PMMA} / \mathrm{CeO}_{2}$ hybrid systems.

Table 2. Onset and difference temperatures $\left({ }^{\circ} \mathrm{C}\right)$ at 10 and $50 \mathrm{wt} \%$ loss of pure PMMA and $\mathrm{PMMA} / \mathrm{CeO}_{2}$ hybrid systems.

\begin{tabular}{|c|c|c|c|c|}
\hline Sample & $T_{0.1}$ & $\Delta T_{0.1}$ & $T_{0.5}$ & $\Delta T_{0.5}$ \\
\hline PMMA & 261 & - & 287 & - \\
\hline PMMA/CeO ${ }_{2}, 0.5$ wt $\%, 120^{\circ} \mathrm{C}$ & 222 & -39 & 360 & 73 \\
\hline PMMA/CeO $2,1.0$ wt $\%, 120^{\circ} \mathrm{C}$ & 178 & -83 & 361 & 74 \\
\hline PMMA/CeO $2,0.5$ wt $\%, 235^{\circ} \mathrm{C}$ & 277 & 16 & 362 & 75 \\
\hline PMMA/CeO ${ }_{2}, 1.0 \mathrm{wt} \%, 235^{\circ} \mathrm{C}$ & 328 & 67 & 365 & 78 \\
\hline PMMA/CeO ${ }_{2}, 0.5 \mathrm{wt} \%, 400{ }^{\circ} \mathrm{C}$ & 291 & 30 & 364 & 77 \\
\hline PMMA/CeO ${ }_{2}, 1.0$ wt $\%, 400{ }^{\circ} \mathrm{C}$ & 316 & 55 & 362 & 75 \\
\hline PMMA/CeO $2,0.5$ wt $\%, 600{ }^{\circ} \mathrm{C}$ & 337 & 76 & 369 & 82 \\
\hline PMMA/CeO $2,1.0$ wt $\%, 600^{\circ} \mathrm{C}$ & 339 & 78 & 366 & 79 \\
\hline PMMA/CeO ${ }_{2}, 0.5$ wt $\%, 800{ }^{\circ} \mathrm{C}$ & 338 & 77 & 367 & 80 \\
\hline PMMA/CeO ${ }_{2}, 1.0$ wt $\%, 800{ }^{\circ} \mathrm{C}$ & 342 & 81 & 369 & 82 \\
\hline
\end{tabular}

The glass transition temperature is generally taken as the inflection point of the specific heat increment at the glass-rubber transition in DSC experiments. Figure 13 shows the effect of $\mathrm{CeO}_{2}$ nanoparticles on the $T_{\mathrm{g}}$ of the PMMA/CeO $\mathrm{Ce}_{2}$ hybrid systems measured by DSC. It can be seen that the incorporation of low contents of $\mathrm{CeO}_{2}$ nanocrystals $(0.5$ and $1.0 \mathrm{wt} \%)$ thermally treated at different temperatures slightly increased the glass transition temperature up to $\sim 125{ }^{\circ} \mathrm{C}$ in comparison with pure PMMA $\sim 121{ }^{\circ} \mathrm{C}$. In agreement with previous reports with other composites $[33,48]$, the trend of the glass transition shifting to a slightly higher temperature is attributed to the electrostatic interactions between the PMMA matrix side chain and $\mathrm{CeO}_{2}$, which hinder the rotation of polymeric chains, leading to increased $T_{\mathrm{g}}$. 

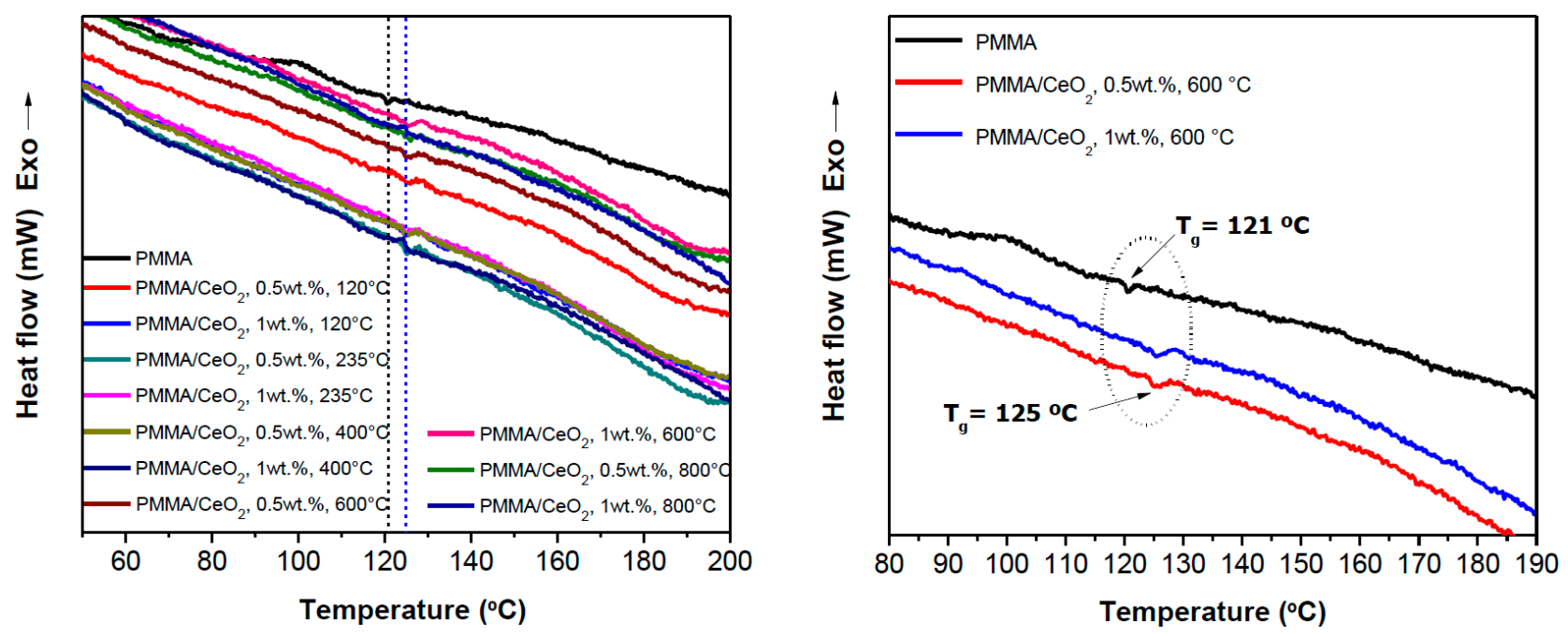

Figure 13. DSC thermograms of the pure PMMA and $\mathrm{PMMA} / \mathrm{CeO}_{2}$ hybrid systems.

\subsubsection{Hardness Tests}

Figure 14 shows typical load-displacement curves obtained in the nanoindentation tests for pure PMMA and PMMA/CeO $\mathrm{C}_{2}$ hybrid systems. It is clear that the addition of $\mathrm{CeO}_{2}$ nanoparticles within PMMA increases the mechanical properties with decreasing penetration depths. For example, for pure PMMA, the maximum indentation depth at maximum load $(5 \mathrm{mN})$ was $1049 \mathrm{~nm}$, whereas with 0.5 and $1.0 \mathrm{wt} \% \mathrm{CeO}_{2}$ thermally treated at $800{ }^{\circ} \mathrm{C}$, the maximum depth was about 874 and $832 \mathrm{~nm}$, respectively.

The hardness $\left(H_{\mathrm{IT}}\right)$, Vickers hardness $\left(H V_{\mathrm{IT}}\right)$, elastic modulus $\left(E_{\mathrm{IT}}\right)$ and creep $\left(C_{\mathrm{IT}}\right)$ results for pure polymer and $\mathrm{PMMA} / \mathrm{CeO}_{2}$ hybrid systems are presented in Table 3. As expected, the $H_{\mathrm{IT}}$ and $H V_{\mathrm{IT}}$ values were increased with nanoceria powders content from 0.5 to $1.0 \mathrm{wt} \%$ as well as with thermal treatment temperature, due to average crystal size and crystallinity of $\mathrm{CeO}_{2}$ nanoparticles. Elastic modulus in the best case (treated samples at 235 and $400{ }^{\circ} \mathrm{C}$ ) enhanced up to $24 \%$, although no clear trend was observed. In general, a decrease in creep displacement has been observed in $\mathrm{PMMA} / \mathrm{CeO}_{2}$ hybrid systems with increasing $\mathrm{CeO}_{2}$ content, showing that the incorporation of rigid $\mathrm{CeO}_{2}$ nanocrystals improves the creep resistance. Finally, the time-dependent deformation of the composites under the applied load was in the range of $2.46 \%-7.48 \%$. In a previous study, similar $H_{\mathrm{IT}}$ and $E_{\mathrm{IT}}$ increments were observed in PMMA nanocomposites with $\mathrm{ZrO}_{2}$ nanoparticles prepared by melt blending and $\mathrm{ZnO}$ nanoparticles synthesized by spin coating [49,50]. This mechanical enhancement is a result of a homogenous dispersion of aggregates combined with an increase in crystallinity of the nanoparticles. Thus, the overall hardness results of as-prepared samples indicate that the $\mathrm{PMMA} / \mathrm{CeO}_{2}$ hybrid systems provide greater stiffness than pure PMMA and therefore are less ductile. 


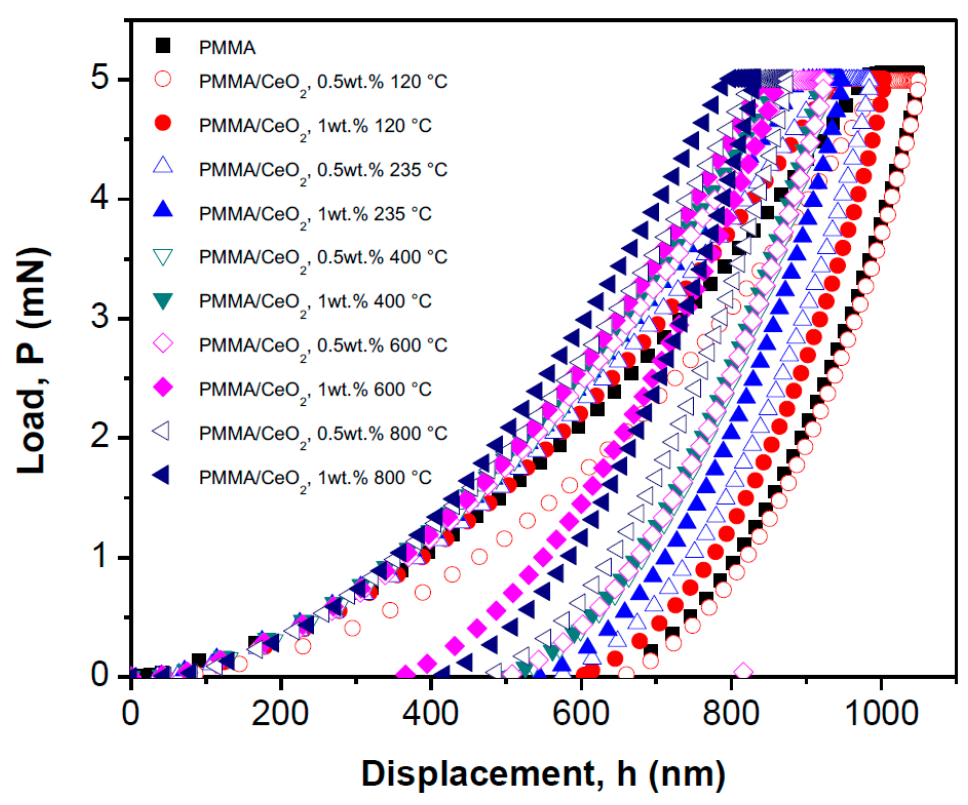

Figure 14. Load-displacement curves of PMMA and $\mathrm{PMMA} / \mathrm{CeO}_{2}$ hybrid systems.

Table 3. Hardness $\left(H_{\mathrm{IT}}\right)$, Vickers hardness $\left(H V_{\mathrm{IT}}\right)$, elastic modulus $\left(E_{\mathrm{IT}}\right)$ and creep $\left(C_{\mathrm{IT}}\right)$ values for pure PMMA and $\mathrm{PMMA} / \mathrm{CeO}_{2}$ hybrid systems.

\begin{tabular}{|c|c|c|c|c|}
\hline Sample & $H_{\text {IT }}(\mathrm{MPa})$ & $H V_{\text {IT }}$ (Vickers) & $E_{\mathrm{IT}}(\mathbf{G P a})$ & $C_{\mathrm{IT}}(\%)$ \\
\hline PMMA & $254 \pm 4$ & $23.5 \pm 0.4$ & $4.10 \pm 0.04$ & $6.97 \pm 0.06$ \\
\hline PMMA/CeO $C_{2}, 0.5 \mathrm{wt} \%, 120^{\circ} \mathrm{C}$ & $246 \pm 4$ & $22.8 \pm 0.6$ & $4.70 \pm 0.05$ & $5.46 \pm 0.08$ \\
\hline PMMA/CeO ${ }_{2}, 1.0 \mathrm{wt} \%, 120^{\circ} \mathrm{C}$ & $277 \pm 5$ & $25.7 \pm 0.3$ & $5.02 \pm 0.03$ & $7.48 \pm 0.09$ \\
\hline PMMA/CeO $2,0.5 \mathrm{wt} \%, 235^{\circ} \mathrm{C}$ & $288 \pm 3$ & $26.7 \pm 0.5$ & $4.87 \pm 0.06$ & $6.65 \pm 0.06$ \\
\hline PMMA/CeO ${ }_{2}, 1.0 \mathrm{wt} \%, 235^{\circ} \mathrm{C}$ & $307 \pm 6$ & $28.4 \pm 0.8$ & $5.09 \pm 0.06$ & $6.78 \pm 0.05$ \\
\hline PMMA/CeO ${ }_{2}, 0.5$ wt $\%, 400{ }^{\circ} \mathrm{C}$ & $332 \pm 5$ & $30.7 \pm 0.6$ & $5.08 \pm 0.04$ & $5.64 \pm 0.08$ \\
\hline PMMA/CeO $2,1.0 \mathrm{wt} \%, 400^{\circ} \mathrm{C}$ & $334 \pm 7$ & $30.9 \pm 0.9$ & $5.04 \pm 0.08$ & $6.31 \pm 0.07$ \\
\hline PMMA/CeO $2,0.5 \mathrm{wt} \%, 600{ }^{\circ} \mathrm{C}$ & $350 \pm 3$ & $32.4 \pm 0.7$ & $4.99 \pm 0.09$ & $5.92 \pm 0.04$ \\
\hline PMMA/CeO $2,1.0 \mathrm{wt} \%, 600^{\circ} \mathrm{C}$ & $439 \pm 9$ & $40.7 \pm 0.6$ & $5.44 \pm 0.05$ & $4.97 \pm 0.09$ \\
\hline PMMA/CeO ${ }_{2}, 0.5$ wt $\%, 800{ }^{\circ} \mathrm{C}$ & $395 \pm 3$ & $36.6 \pm 0.3$ & $5.73 \pm 0.09$ & $5.82 \pm 0.05$ \\
\hline PMMA/CeO $2,1.0 \mathrm{wt} \%, 800^{\circ} \mathrm{C}$ & $466 \pm 8$ & $43.2 \pm 0.4$ & $4.21 \pm 0.07$ & $2.46 \pm 0.09$ \\
\hline
\end{tabular}

\section{Conclusions}

Fluorite phase $\mathrm{CeO}_{2}$ nanoparticles were successfully synthesized by the sol-gel method and their structure and nanocrystallite size were confirmed by XRD and TEM measurements. Similarly, the $\mathrm{PMMA} / \mathrm{CeO}_{2}$ hybrid systems were prepared using conventional single-screw melt compounding and were systematically investigated as a function of the amount and thermal treatment temperature of inorganic nanoparticles. ${ }^{1} \mathrm{H}$ NMR spectra revealed only the presence of electrostatic interactions between the PMMA and $\mathrm{CeO}_{2}$ nanoparticles. The XRD analysis showed that the incorporation of $\mathrm{CeO}_{2}$ into the polymer did not change the amorphous structure of the PMMA. The $\mathrm{PMMA} / \mathrm{CeO}_{2}$ hybrid systems showed substantially lower UV transmission than pure PMMA. Transparency of the hybrid systems decreased with the amount of nanoceria loading in the PMMA because of the structural phase and agglomeration of $\mathrm{CeO}_{2}$ nanoparticles. UV transmission in $\mathrm{PMMA} / \mathrm{CeO}_{2}$ hybrid systems with 0.5 wt \% of 
nanoparticles varies from $10 \%$ to $19 \%$ in the $250-350 \mathrm{~nm}$ region, whereas it was close to zero with 1.0 wt $\%$. Thus, only samples $\mathrm{PMMA} / \mathrm{CeO}_{2}$ with $0.5 \mathrm{wt} \%$ of nanoparticles sintered at $400{ }^{\circ} \mathrm{C}$ showed a balance between UV absorption, color of the material and transparency, which is a necessary condition for building applications. Nevertheless, the other systems that displayed excellent UV-shielding properties are expected to be applied in multifunctional materials industry.

The addition of nanoceria powders increases the degradation and glass transition temperatures of PMMA, independently of the thermal treatment temperature and $\mathrm{CeO}_{2}$ content, which was the result of a homogeneous dispersion of the aggregates and the restriction of mobility of polymer chains. Nanoindentation revealed that the hardness and elastic modulus increase with raising the particle contents and thermal treatment temperature. Finally, these results demonstrate that the crystalline $\mathrm{CeO}_{2}$ particles are useful fillers to increase the mechanical properties of PMMA.

\section{Acknowledgments}

María A. Reyes-Acosta is grateful for her postgraduate scholarship from SIP-IPN. The authors are also grateful for the financial support provided by CONACYT through the CB2009-132660 and CB2009-133618 projects and to IPN through the SIP 2015-0227 and 2015-0202 projects and SNI-CONACYT. Thanks to Adela E. Rodríguez-Salazar for her technical support during the revision of the manuscript.

\section{Author Contributions}

María A. Reyes-Acosta, Aidé M. Torres-Huerta and Aberlardo I. Flores-Vela designed the experiments. Maria A. Reyes-Acosta performed the experiments and analyzed the data. Héctor J. Dorantes-Rosales and José A. Andraca-Adame performed the morphological characterization. María A. Reyes-Acosta and Miguel A. Domínguez-Crespo wrote the manuscript. Aidé M. Torres-Huerta directed the research, provided the funds and revised the manuscript.

\section{Conflicts of Interest}

The authors declare no conflict of interest.

\section{References}

1. Gutierrez, M.P.; Zohdi, T.I. Effective reflectivity and heat generation in sucrose and PMMA mixtures. Energy Build. 2014, 71, 95-103. [CrossRef]

2. Demir, M.M.; Memesa, M.; Castignolles, P.; Wegner, G. PMMA/zinc oxide nanocomposites prepared by in-situ bulk polymerization. Macromol. Rapid Commun. 2006, 27, 763-770. [CrossRef]

3. Gross, S.; Camozzo, D.; Noto, V.D.; Armelao, L.; Tondello, E. PMMA: A key macromolecular component for dielectric low- $\kappa$ hybrid inorganic-organic polymer films. Eur. Polym. J. 2007, 43, 673-696. [CrossRef]

4. Soumya, S.; Mohamed, A.P.; Paul, L.; Mohan, K.; Ananthakumar, S. Near IR reflectance characteristics of PMMA/ZnO nanocomposites for solar thermal control interface films. Sol. Energy Mater. Sol. Cells 2014, 125, 102-112. [CrossRef]

5. Weon, J.I.; Creasy, T.S.; Sue, H.J.; Hsieh, A.J. Mechanical behavior of polymethylmethacrylate with molecules oriented via simple shear. Polym. Eng. Sci. 2005, 45, 314-324. [CrossRef] 
6. Saadat-Monfared, A.; Mohseni, M.; Tabatabaei, M.H. Polyurethane nanocomposite films containing nano-cerium oxide as UV absorber. Part 1. Static and dynamic light scattering, small angle neutron scattering and optical studies. Colloids Surf. A Physicochem. Eng. Asp. 2012, 408, 64-70. [CrossRef]

7. Cui, H.; Zayat, M.; Parejo García, P.; Levy, D. Highly eficcient inorganic transparent UV-Protective thion-film coating by low temperature sol-gel procedure for application on heat sensitive substrates. Adv. Mater. 2008, 20, 65-68. [CrossRef]

8. Sugumaran, S.; Bellan, C.S. Transparent nanocomposite $\mathrm{PVA}^{-\mathrm{TiO}_{2}}$ and $\mathrm{PMMA}^{-T i O}{ }_{2}$ thin films: Optical and dielectric properties. Opt. Int. J. Light Electron Opt. 2014, 125, 5128-5133. [CrossRef]

9. Laachachi, A.; Ferriol, M.; Cochez, M.; Ruch, D.; Lopez-Cuesta, J.M. The catalytic role of oxide in the thermooxidative degradation of poly(methyl methacrylate)- $\mathrm{TiO}_{2}$ nanocomposites. Polym. Degrad. Stab. 2008, 93, 1131-1137. [CrossRef]

10. Soumya, S.; Mohamed, A.P.; Mohan, K.; Ananthakumar, S. Enhanced near-infrared reflectance and functional characteristics of Al-doped $\mathrm{ZnO}$ nano-pigments embedded PMMA coatings. Sol. Energy Mater. Sol. Cells 2015, 143, 335-346. [CrossRef]

11. Zhang, L.; Li, F.; Chen, Y.; Wang, X. Synthesis of transparent ZnO/PMMA nanocomposite films through free-radical copolymerization of asymmetric zinc methacrylate acetate and in-situ thermal decomposition. J. Lumin. 2011, 131, 1701-1706. [CrossRef]

12. Zhang, Y.; Zhuang, S.; Xu, X.; Hu, J. Transparent and UV-shielding ZnO@PMMA nanocomposite films. Opt. Mater. 2013, 36, 169-172. [CrossRef]

13. $\mathrm{Hu}, \mathrm{J} . ;$ Zhou, Y.; He, M.; Yang, X. Novel polysiloxane@ $\mathrm{CeO}_{2}-\mathrm{PMMA}$ hybrid materials for mechanical application. Mater. Lett. 2014, 116, 150-153. [CrossRef]

14. Lima, J.F.; Martins, R.F.; Neri, C.R.; Serra, O.A. $\mathrm{ZnO}: \mathrm{CeO}_{2}$-based nanopowders with low catalytic activity as UV absorbers. Appl. Surf. Sci. 2009, 255, 9006-9009. [CrossRef]

15. Aklalouch, M.; Calleja, A.; Granados, X.; Ricart, S.; Boffa, V.; Ricci, F.; Puing, T.; Obradors, X. Hybrid sol-gel layers containing $\mathrm{CeO}_{2}$ nanoparticles as UV-protection of plastic lenses for concentrated photovoltaics. Sol. Energy Mater. Sol. Cells 2014, 120, 175-182. [CrossRef]

16. Panahi-Kalamuei, M.; Alizadeh, S.; Mousavi-Kamazani, M. Synthesis and characterization of $\mathrm{CeO}_{2}$ nanoparticles via hydrothermal route. J. Ind. Eng. Chem. 2015, 21, 1301-1305. [CrossRef]

17. Khan, S.B.; Faisal, M.; Rahman, M.M.; Jamal, A. Exploration of $\mathrm{CeO}_{2}$ nanoparticles as a chemi-sensor and photo-catalyst for environmental applications. Sci. Total Environ. 2011, 409, 2987-2992. [CrossRef] [PubMed]

18. Taguchi, M.; Takami, S.; Adschiri, T.; Nakane, T.; Sato, K.; Naka, T. Supercritical hydrothermal synthesis of hydrophilic polymer-modified water-dispersible $\mathrm{CeO}_{2}$ nanoparticles. Cryst. Eng. Comm. 2011, 13, 2841-2848. [CrossRef]

19. Ivanov, V.K.; Shaporev, A.S.; Kiryukhin, D.P.; Bol'shakov, A.I.; Gil, D.O.; Kichigina, G.A.; Kozik, V.V.; Buznik, V.M.; Tretyakov, Y.D. Synthesis of polymer composites based on nanocrystalline $\mathrm{ZnO}$ and $\mathrm{CeO}_{2}$. Dokl. Chem. 2010, 431, 109-112. [CrossRef]

20. Pati, R.K.; Lee, I.C.; Chu, D.; Hou, S.; Ehrman, S.H. Nanosized ceria based water-gas shift (WGS) catalyst for fuel cell applications. Prepr. Pap. Am. Chem. Soc. Div. Fuel Chem. 2004, 49, 953-954. 
21. Ansari, A.A. Optical and structural properties of sol-gel derived nanostructured $\mathrm{CeO}_{2}$ film. J. Semicond. 2010, 31, 053001. [CrossRef]

22. Liu, B.; Liu, B.; Li, Q.; Li, Z.; Liu, R.; Zou, X.; Wu, W.; Cui, W.; Liu, Z.; Li, D.; et al. Solvothermal synthesis of monodisperse self-assembly $\mathrm{CeO}_{2}$ nanospheres and their enhanced blue-shifting in ultraviolet absorption. J. Alloys Compd. 2010, 503, 519-524. [CrossRef]

23. Phonthammachai, N.; Rumruangwong, M.; Gulari, E.; Jamieson, A.M.; Jitkarnka, S. Synthesis and rheological properties of mesoporous nanocrystalline $\mathrm{CeO}_{2}$ via sol-gel process. Colloids Surf. A Physicochem. Eng. Asp. 2004, 247, 61-68. [CrossRef]

24. Podzorova, L.I.; Il'icheva, A.A.; Mikhailina, N.A.; Shevchenko, V.Y.; Bashlykov, D.S.; Rodicheva, G.V.; Shvorneva, L.I. Effect of synthesis conditions on the phase composition of $\mathrm{ZrO}_{2}-\mathrm{CeO}_{2}-\mathrm{AlO}_{3}$ sol-gel powders. Inorg. Mater. 2001, 37, 51-57. [CrossRef]

25. Mamana, N.; Díaz-Parralejo, A.; Ortiz, A.L.; Sánchez-Bajo, F.; Caruso, R. Influence of the synthesis process on the features of $\mathrm{Y}_{2} \mathrm{O}_{3}$-stabilized $\mathrm{ZrO}_{2}$ powders obtained by the sol-gel method. Ceram. Int. 2014, 40, 6421-6426. [CrossRef]

26. Dos Santos, V.; da Silveira, N.P.; Bergmann, C.P. In-situ evaluation of particle size distribution of $\mathrm{ZrO}_{2}$-nanoparticles obtained by sol-gel. Powder Technol. 2014, 267, 392-397. [CrossRef]

27. Chen, Y.; Li, Z.; Miao, N. Polymethylmethacrylate (PMMA)/CeO $\mathrm{C}_{2}$ hybrid particles for enhanced chemical mechanical polishing performance. Tribol. Int. 2015, 82, 211-217. [CrossRef]

28. Oliver, W.C.; Pharr, G.M. Measurement of hardness and elastic modulus by instrumented indentation: Advances in understanding and refinements to methodology. J. Mater. Res. 2004, 19, 3-20. [CrossRef]

29. Andreescu, D.; Matijevć, E.; Goia, D.V. Formation of uniform colloidal ceria in polyol. Colloids Surf. A Physicochem. Eng. Asp. 2006, 291, 93-100. [CrossRef]

30. Truffault, L.; Andrezza, C.; Santilli, C.V.; Pulcinelli, S.H. Synthesis of PTSH-modified $\mathrm{CeO}_{2}$ nanoparticles: Effect of the modifier on structure, optical properties, and dispersibility. Colloids Surf. A Physicochem. Eng. Asp. 2013, 426, 63-69. [CrossRef]

31. Lee, J.-S.; Choi, S.C. Crystallization behavior of nano-ceria powders by hydrothermal synthesis using a mixture of $\mathrm{H}_{2} \mathrm{O}_{2}$ and $\mathrm{NH}_{4} \mathrm{OH}$. Mater. Lett. 2004, 58, 390-393. [CrossRef]

32. Liu, J.; Zhao, Z.; Wang, J.; Xu, C.; Duan, A.; Jiang, G.; Yang, Q. The highly active catalysts of nanometric $\mathrm{CeO}_{2}$-supported cobalt oxides for soot combustion. Appl. Catal. B 2008, 84, 185-195. [CrossRef]

33. Padalia, D.; Bisht, G.; Johri, U.C.; Asokan, K. Fabrication and characterization of cerium doped barium titanate/PMMA nanocomposites. Solid State Sci. 2013, 19, 122-129. [CrossRef]

34. Cullity, B.D.; Stock, S.R. Elements of X-ray Diffraction, 3rd ed.; Prentice Hall: Upper Saddle River, NJ, USA, 2001; pp. 167-170.

35. Su, W.; Wang, S.; Wang, X.; Fu, X.; Weng, J. Plasma pre-treatment and $\mathrm{TiO}_{2}$ coating of PMMA for the improvement of antibacterial properties. Surf. Coat. Technol. 2010, 205, 465-469. [CrossRef]

36. Sathish, S.; Shekar, B.C. Preparation and characterization of nano scale PMMA thin films. Indian J. Pure Appl. Phys. 2014, 52, 64-67.

37. Marsalek, R. Particle size and zeta potential of ZnO. APCBEE Proced. 2014, 9, 13-17. [CrossRef] 
38. Díez-Pascual, A.M.; Gómez-Fatou, M.A.; Ania, F.; Flores, A. Nanoindentation in polymer nanocomposites. Prog. Mater. Sci. 2015, 67, 1-94. [CrossRef]

39. Yang, Y.; Mao, P.; Wang, Z.-P.; Zhang, J.-H. Distribution of nanoparticle number concentrations at a nano- $\mathrm{TiO}_{2}$ plant. Aerosol Air Qual. Res. 2012, 12, 934-940. [CrossRef]

40. Leong, K.H.; Monash, P.; Ibrahim, S.; Saravanan, P. Solar photocatalytic activity of anatase $\mathrm{TiO}_{2}$ nanocrystals synthesized by non-hydrolitic sol-gel method. Sol. Energy 2014, 101, 321-332. [CrossRef]

41. Huang, Y.; Cai, Y.; Qiao, D.; Liu, H. Morphology-controllable synthesis and characterization of $\mathrm{CeO}_{2}$ nanocrystals. Particuology 2011, 9, 170-173. [CrossRef]

42. Wu, X.; Wang, Y.; Zhu, P.; Sun, R.; Yu, S.; Du, R. Using UV-Vis spectrum to investigate the phase transition process of PMMA-SiO ${ }_{2} @$ paraffin microcapsules with copper-chelating as the ion probe. Mater. Lett. 2011, 65, 705-707. [CrossRef]

43. Shirai, M.; Yamamoto, T.; Tsunooka, M. Ablative photodegradation of poly(methyl methacrylate) and its homologues by 185-nm light. Polym. Degrad. Stab. 1999, 63, 481-487. [CrossRef]

44. Kashiwagi, T.; Inaba, A.; Brown, J.E.; Hatada, K.; Kitayama, T.; Masuda, E. Effects of weak linkages on the thermal and oxidative degradation of poly(methyl methacrylate). Macromolecules 1986, 19, 2160-2168. [CrossRef]

45. Zhu, L.Y.; Wang, X.Q.; Ren, Q.; Zhang, G.H.; Xu, D. Morphology and crystal structure of $\mathrm{CeO}_{2}$-modified mesoporous $\mathrm{ZrO}_{2}$ powders prepared by sol-gel method. Mater. Chem. Phys. 2012, 133, 445-451. [CrossRef]

46. Dzunuzovic, E.S.; Dzunuzovic, J.V.; Marinkovic, A.D.; Marinovic-Cincovic, M.T.; Jeremic, K.B.; Nedeljkovic, J.M. Influence of surface modified $\mathrm{TiO}_{2}$ nanoparticles by gallates on the properties of PMMA/TiO 2 nanocomposites. Eur. Polym. J. 2012, 48, 1385-1393. [CrossRef]

47. Zhao, Q.; Samulski, E.T. A comparative study of poly(methyl methacrylate) and polystyrene/clay nanocomposites prepared in supercritical carbon dioxide. Polymer 2006, 47, 663-671. [CrossRef]

48. Parker, K.; Schneider, R.T.; Siegel, R.W.; Ozisik, R.; Cabanelas, J.C.; Serrano, B.; Antonelli, C.; Baselga, J. Molecular probe technique for determining local thermal transitions: The glass transition at silica/PMMA nanocomposite interfaces. Polymer 2010, 51, 4891-4898. [CrossRef]

49. Chakraborty, H.; Sinha, A.; Mukherjee, N.; Ray, D.; Chattopadhyay, P.P. A study on nanoindentation and tribological behavior of multifunctional ZnO/PMMA nanocomposite. Mater. Lett. 2013, 93, 137-140. [CrossRef]

50. Reyes-Acosta, M.A.; Torres-Huerta, A.M.; Domínguez-Crespo, M.A.; Flores-Vela, A.I.; Dorantes-Rosales, H.J.; Ramírez-Meneses, E. Influence of $\mathrm{ZrO}_{2}$ nanoparticles and termal treatmentontheproperties of $\mathrm{PMMA}_{2} \mathrm{ZrO}_{2}$ hybridcoatings. J. Alloy. Compd. 2015, 643, S150-S158. [CrossRef]

(C) 2015 by the authors; licensee MDPI, Basel, Switzerland. This article is an open access article distributed under the terms and conditions of the Creative Commons Attribution license (http://creativecommons.org/licenses/by/4.0/). 